\title{
SURFEX v8.0 interface with OASIS3-MCT to couple atmosphere with hydrology, ocean, waves and sea-ice models, from coastal to global scales
}

\author{
Aurore Voldoire ${ }^{1}$, Bertrand Decharme ${ }^{1}$, Joris Pianezze ${ }^{2,4}$, Cindy Lebeaupin Brossier ${ }^{1}$, Florence Sevault ${ }^{1}$, \\ Léo Seyfried $^{3}$, Valérie Garnier ${ }^{2}$, Soline Bielli $^{4}$, Sophie Valcke ${ }^{5}$, Antoinette Alias ${ }^{1}$, Mickael Accensi ${ }^{2}$, \\ Fabrice Ardhuin ${ }^{2}$, Marie-Noëlle Bouin ${ }^{1,2}$, Véronique Ducrocq ${ }^{1}$, Stéphanie Faroux ${ }^{1}$, Hervé Giordani ${ }^{1}$, Fabien Léger ${ }^{1}$, \\ Patrick Marsaleix $^{3}$, Romain Rainaud ${ }^{1}$, Jean-Luc Redelsperger ${ }^{2}$, Evelyne Richard ${ }^{3}$, and Sébastien Riette ${ }^{1}$ \\ ${ }^{1}$ Centre National de Recherches Météorologiques, CNRM, Météo-France/CNRS UMR3589, Toulouse, France \\ ${ }^{2}$ Laboratoire d'Océanographie Physique et Spatiale, LOPS, CNRS UMR6523/Ifremer/IRD/UBO, Brest, France \\ ${ }^{3}$ Laboratoire d'Aérologie, LA, CNRS UMR5560/Université de Toulouse, Toulouse, France \\ ${ }^{4}$ Laboratoire de l'Atmosphère et des Cyclones, LACy, CNRS UMR8105/Université de la Réunion/Météo-France, \\ Saint Denis de la Réunion, France \\ ${ }^{5}$ CECI, Université de Toulouse, CNRS UMR5318, CERFACS, Toulouse, France
}

Correspondence to: Aurore Voldoire (aurore.voldoire@meteo.fr)

Received: 3 April 2017 - Discussion started: 8 May 2017

Revised: 15 September 2017 - Accepted: 4 October 2017 - Published: 20 November 2017

\begin{abstract}
This study presents the principles of the new coupling interface based on the SURFEX multi-surface model and the OASIS3-MCT coupler. As SURFEX can be plugged into several atmospheric models, it can be used in a wide range of applications, from global and regional coupled climate systems to high-resolution numerical weather prediction systems or very fine-scale models dedicated to process studies. The objective of this development is to build and share a common structure for the atmosphere-surface coupling of all these applications, involving on the one hand atmospheric models and on the other hand ocean, ice, hydrology, and wave models. The numerical and physical principles of SURFEX interface between the different component models are described, and the different coupled systems in which the SURFEX OASIS3-MCT-based coupling interface is already implemented are presented.
\end{abstract}

\section{Introduction}

In the late $80 \mathrm{~s}$, the first coupled systems assembling atmosphere and ocean models were developed for climate-scale studies. The interactions between the atmosphere and the ocean need undeniably to be properly represented when considering the climate system on long timescales. Seasonal forecasting also called for such coupled models. Indeed, El Niño-Southern Oscillation (ENSO) is one of the main processes that drive the predictability at the seasonal scale and is in essence a coupled process that cannot be simulated by an atmospheric model or by an oceanic model alone. In the last decade, general circulation models (GCMs) have progressively evolved to become Earth system models (ESMs) by including other components such as sea-ice, carbon cycle, chemistry and continental hydrology. In the meantime, regional climate system models (RCSMs) coupling atmosphere and ocean limited-area models have been developed. They have shown their usefulness in increasing the reliability of regional climate information in areas where local and complex interactions and feedbacks between the different components of the system are important such as in the 
Mediterranean region (MED-CORDEX initiative; Ruti et al., 2016).

Higher-resolution $(<\sim 5 \mathrm{~km}$ resolution) modelling systems generally used for numerical weather prediction (NWP) and fine-scale process studies are rarely coupled systems, arguing that the ocean evolves on much slower timescales than the atmosphere. However, there are some exceptions for which an immediate response of the ocean to the atmospheric weather is observed, with short-time, intense and localized interactions between the two components, as such encountered during extreme weather events (e.g. tropical cyclones, strong winds and storms at mid-latitudes, heavy precipitation events). The first ocean-atmosphere high-resolution coupled systems appeared at the beginning of the 2000s to study these interactions (e.g. Pullen et al., 2003; Ren et al., 2004; Loglisci et al., 2004). Nowadays, the development of highresolution, short- to medium-range coupled prediction systems is still challenging, but several groups have undertaken it, based on coupling methods with different levels of sophistication and targeting a large range of applications depending on their interests (Brassington et al., 2015; Heinzeller et al., 2016; Hewitt et al., 2016; Janssen et al., 2013).

From a technical point of view, different approaches can be followed to implement the coupling between existing model components. A first approach is fully embedded coupling, i.e. assembling components into one executable in a hardcoded way, using or not classes and methods from coupling toolkits such as the Model Coupling Toolkit (MCT, Larson et al., 2005). One example is the Coupled Ocean-AtmosphereWave-Sediment-Transport system (COAWST, Warner et al., 2010) that uses directly the MCT library and the Spherical Coordinate Remapping Interpolation Package (SCRIP, Jones, 1999) to assemble into one executable the Weather Research and Forecasting (WRF, Skamarock et al., 2008) atmospheric model, the Regional Ocean Modeling System (ROMS, Shchepetkin and McWilliams, 2005) oceanic model, the Simulating WAves Nearshore (SWAN, Booij et al., 1999) wave model and the Community Sediment Transport Model (CSTMS, Warner et al., 2008). COAWST was notably used at high resolutions (up to $3 \mathrm{~km}$ for the atmosphere and up to $1 \mathrm{~km}$ for the ocean and wave models) over several places in the Mediterranean region (Renault et al., 2012; Carniel et al., 2016; Ricchi et al., 2016). These studies highlight that high-resolution coupling improves significantly the simulation results.

As fully embedded hard-coded coupling restricts the modularity of the coupled system and the reuse of its components, many coupled systems are built using instead higherlevel coupling technologies specifically developed for that purpose. These coupling technologies can be roughly divided into two categories, both including the ability to exchange data between components, interpolate data on different grids and manage the time evolution of the model integration.

In the first category, coupling is achieved via componentlevel interfaces within one integrated application, e.g. the
Earth System Modeling Framework (ESMF, https://www. earthsystemcog.org/projects/esmf/, Collins et al., 2005; Theurich et al., 2016), and requires splitting of the components into initialize, run, and finalize parts. This approach limits the places where data exchanges can happen, but offers opportunities for performance optimization, as components can be easily run in different layouts on available resources. An example of a coupled system using ESMF is the Coupled Ocean-Atmosphere Mesoscale Prediction System (COAMPS ${ }^{\circledR}$ ) developed by the Naval Research Laboratory (NRL) and run in operations by the U.S. Department of Defense. In that case, an ESMF coupler component receives variables from the ocean model and from the atmospheric model to compute the air-sea exchanges on an intermediate grid, and then sends them back to the two component models. COAMPS also includes nesting capability in the two components and a coupled data assimilation scheme. This system was used in particular over the Adriatic Sea and the Ligurian Sea to evaluate the air-sea interactions during strong wind events, bora and mistral, with resolutions of up to $4 \mathrm{~km}$ in the atmosphere and $2 \mathrm{~km}$ in the ocean (Pullen et al., 2006, 2007; Small et al., 2011, 2012). A configuration of COAMPS, named COAMPS-TC, was also specifically designed to improve tropical cyclone forecasts (Doyle et al., 2014).

The second category of coupling technologies implements coupling between multiple executables running concurrently. OASIS3-MCT (Craig et al., 2017) is one widely used representative software of that second category. This approach requires a minimal amount of modification in existing component codes, but limits the ways they can be run on available computing resources, which can hinder performance. For example, if the components are sequentially coupled (i.e. one component cannot do any work while the other is running to produce its coupling field and vice versa), running concurrently on different sets of resources will lead to some waste of resources.

This paper presents the development of a standard coupling interface in the SURFEX surface modelling platform (Masson et al., 2013) based on OASIS3-MCT to couple atmospheric models with a variety of hydrological, ocean, wave and sea-ice models. SURFEX is open-source software that represents the evolution of surface-atmosphere fluxes considering four surface types (land, town, ocean and inland waters). As SURFEX is a fully externalized surface model, it can be used in stand-alone mode, i.e. driven by a prescribed atmospheric state, or embedded in an atmospheric model. The coupling with atmospheric models is done via a standard hard-coded coupling interface (Best et al., 2004). When used with an atmospheric model, SURFEX necessarily operates on the same grid. SURFEX is implemented in the following atmospheric models: ARPEGE (Courtier et al., 1991), the Météo-France global model for NWP and climate (Déqué et al., 1994); ALADIN (Fischer et al., 2005), the limited-area configuration of ARPEGE initially developed 
for NWP and now used for regional climate (Spiridonov et al., 2005; Radu et al., 2008); AROME, the non-hydrostatic limited-area model in operation at Météo-France (Seity et al., 2011) and the derived HARMONIE configuration used by the HIRLAM consortium; and MESONH (Lafore et al., 1998), a research oriented non-hydrostatic atmospheric model developed jointly by the Laboratoire d'Aérologie and CNRM. SURFEX is based on a 1-D modelling approach, which means that its physical schemes represent only local vertical processes without any information from the neighbouring grid points, and thus there is no horizontal exchange between the different grid points. This limits the modelling of river flows in SURFEX, which is in essence a water transfer between grid points. Similarly, the ocean can only be represented as a collection of single water columns.

The introduction of a standard OASIS3-MCT coupling interface in SURFEX allows more sophisticated 2-D or 3-D modelling for representing the evolution of the four surface types considered, as well as using different grids for the ocean, ice, wave or hydrological models. A standard coupling interface has been preferred to embedded couplings as it helps the use of various models for each component depending on the application and fosters interoperability between the models. It allows us also to benefit more easily and rapidly from modelling advances achieved by each model community. Developing a standard interface in SURFEX to couple it with ocean, wave and hydrological models thus means that SURFEX can be coupled in stand-alone applications, but also that all the atmospheric models listed above can be coupled.

OASIS3-MCT was chosen as a coupling interface in SURFEX for its flexibility and because OASIS3 was already used for previous versions of the ARPEGE climate model coupled to the NEMO ocean model (Voldoire et al., 2013). The new coupling interface described here benefits from this past experience of using OASIS3 for ocean-atmosphere coupling, but enlarges its objectives: (i) to ease the use of the coupling interface for other applications based on SURFEX, (ii) to enable the coupling with SURFEX both in stand-alone mode and embedded in an atmospheric model, and (iii) to replace OASIS3 by OASIS3-MCT that offers increased parallelism better adapted to new computer architectures.

This paper describes the numerical and physical principles of the standard coupling interface in Sect. 2. Section 3 provides several examples illustrating use cases of the interface, ranging from climate applications to process oriented studies with mesoscale models. Conclusions and perspectives are given in Sect. 4.

\section{Principles of the SURFEX-based coupling using OASIS3-MCT}

\subsection{SURFEX brief description}

A complete description of SURFEX can be found in Masson et al. (2013). In summary, SURFEX computes the surface prognostic variables (surface temperature, radiative temperature, roughness length, albedo, emissivity) and fluxes (evaporation and evapotranspiration, sensible and latent heat fluxes, wind stress) taking into account the evolution of four types of surfaces: land, water, ocean and town. To do so, the SURFEX model includes various schemes.

- For the land surface type, the "Interactions between Soil, Biosphere, and Atmosphere" (ISBA) scheme (Noilhan and Planton, 1989) is used. Several parameterizations are available in ISBA to represent the evolution of continental natural surfaces including bare soils, rocks, permanent snow, glaciers, natural vegetation and agricultural landscapes.

- Fluxes over sea and ocean are obtained with bulk parameterizations, either direct like Louis (1979)'s scheme or iterative like the "Exchange Coefficients from Unified Multicampaign Estimates" (ECUME; Belamari, 2005; Belamari and Pirani, 2007) or the "Coupled Ocean-Atmosphere Response Experiment" (COARE; Fairall et al., 2003) parameterizations.

- Inland water (including lakes and rivers) fluxes are treated with the Charnock (1955) formulation or with the FLAKE scheme (Mironov, 2010).

- When it is not considered as rocks, urban (town) surface (including buildings, roads and transportation infrastructures, and gardens) is modelled using the Town Energy Budget (TEB) scheme (Masson, 2000).

The surface-atmosphere fluxes are then aggregated for each atmospheric grid cell, according to the fraction of the four types of surface in the cell. The averaged value $(F)$ over the grid cell is thus given by

$F=c_{\text {land }} F_{\text {land }}+c_{\text {ocean }} F_{\text {ocean }}+c_{\text {lake }} F_{\text {lake }}+c_{\text {town }} F_{\text {town }}$

where $F_{\text {land }}, F_{\text {ocean }}, F_{\text {lake }}, F_{\text {town }}$ and $c_{\text {nature }}, c_{\text {ocean }}, c_{\text {lake }}, c_{\text {town }}$ are the surface-atmosphere fluxes and fraction of each type within the grid cell for land, ocean, inland water and town, respectively.

\subsection{OASIS3-MCT}

OASIS developed by CERFACS since 1991 is now interfaced with MCT (Larson et al., 2005). OASIS3-MCT (Craig et al., 2017) is a coupling library whose main function is to exchange and interpolate fields between various codes modelling the different components of a coupled system. Thanks 
to MCT, all transformations are executed in parallel on the source or target processes and parallel coupling exchanges are executed via the Message Passing Interface (MPI) directly between the component models. The OASIS3-MCT coupling library no longer needs dedicated processes to run, as was the case for the previous OASIS3 version (Valcke, 2013). With the introduction of MCT, the computing cost of the coupling is reduced and is now rather negligible compared to the integration time of the component models (see Sect. 3).

OASIS3-MCT is a flexible tool that allows the user to configure the coupling algorithm and type of interpolations in a namelist file called "namcouple" without modifying the source code. For instance, in all the examples presented in Sect. 3, the coupled components run concurrently and exchange their coupling fields at the end of the coupling time step. This means that for a given coupling time period, the atmospheric model sees the surface fields from the former coupling period and the other models see the fluxes computed by the atmosphere during the former coupling period too. The models coupled through OASIS3-MCT could also be run sequentially depending on the namcouple configuration. However, as explained in the introduction, such a configuration would be less efficient in terms of computational resource use since the different models of the coupled system run on distinct sets of resources and since one model would wait while the other is running and vice versa.

Finally, there are several types of interpolation available in OASIS3-MCT (conservative, bilinear, distance weighted, etc.) that can be specifically defined for each coupling field in the namcouple file. For more details on the OASIS3-MCT possibilities, the reader is referred to the documentation distributed with the code (Valcke et al., 2015).

\subsection{Interfacing of the SURFEX surface modelling platform with OASIS3-MCT}

The standard coupling interface with OASIS3-MCT has been part of the SURFEX open-source code suite since release v8.0, except for the additional code for exchanges with a wave model which will soon be available with version v8.1. Including OASIS3-MCT subroutine calls in SURFEX v8.0 source code (in the subroutines indicated in italics between parentheses) was done as follows:

1. initialization (sfx_oasis_init) and namelist reading (sfx_oasis_read_nam);

2. multi-process partition definition and listing of the exchanged fields (sfx_oasis_define);

3. receiving (sfx_oasis_recv) and sending (sfx_oasis_send) of the coupling fields;

4. finalization (sfx_oasis_end).

Steps 1, 2 and 4, which correspond to preparation and closure of the coupling, are either called by SURFEX itself when
SURFEX runs stand-alone or by the atmospheric model when it integrates SURFEX (because the parallelization information to be sent to OASIS3-MCT is then managed by the atmospheric model). Receiving and sending actions are directly called by SURFEX in both modes.

The list of coupling fields is specified by the user in the SURFEX namelist. There is one Boolean (LOASIS) to activate the coupling and three variables to indicate the coupling time step for each coupled component model (hydrology, ocean and waves). The coupling with one component is activated when its coupling time step is positive. The field names have to be specified accordingly in the OASIS3-MCT namelist, and for each field the user specifies the type of interpolation and the coupling period. Before running the coupled system, the files defining the coupled grids and containing the coupled fields for the initial coupling step (also called restarts) can be either prepared by the user or automatically generated using the SURFEX PREP tool (see the OASIS3MCT documentation for more details on these files). The grids and masks automatically defined may be not suitable for limited-area coupled model configurations. For instance, in the case of coupling with an ocean model in limited-area configurations, the atmospheric and oceanic domains do not match exactly in general. In practice, atmospheric grids are always chosen to cover a larger domain than oceanic grids. OASIS3-MCT interpolates the ocean model SSTs to a domain smaller that the atmospheric effective domain and the atmospheric model is forced by a user-prescribed SST field outside the domain corresponding to the ocean model domain. In this case, the user has to define by himself the mask for receiving the oceanic fields on the atmospheric grid, in the OASIS3-MCT grid definition files.

At the time of the coupling interface development, some atmospheric models were using SURFEX versions older than v8.0; the coupling interface has thus been back-phased in former versions of SURFEX. As this implementation is relatively independent of the physical part of the code, the backphasing was relatively easy, and this puts some confidence in the maintainability of the OASIS3-MCT interface in the SURFEX code. The examples of coupled systems presented in Sect. 3 used either SURFEX v8.0 or former versions of SURFEX. Progressively, all the atmospheric models interfaced with SURFEX will use the SURFEX v8.0 release or later ones, meaning that the coupling interface will be available in all the atmospheric models interfaced with SURFEX.

\subsection{Flow chart of the coupling exchanges}

The complete flow chart of the coupling exchanges between SURFEX (embedded or not in an atmospheric model ATM), an ocean model (OCE) with sea ice (ICE), a wave model (WAV) and a hydrological model (HYD) is shown in Fig. 1. The coupling with such components is intended to be generic and not dependent on the models used for OCE, ICE, WAV and HYD. This was only verified for OCE, as either the 


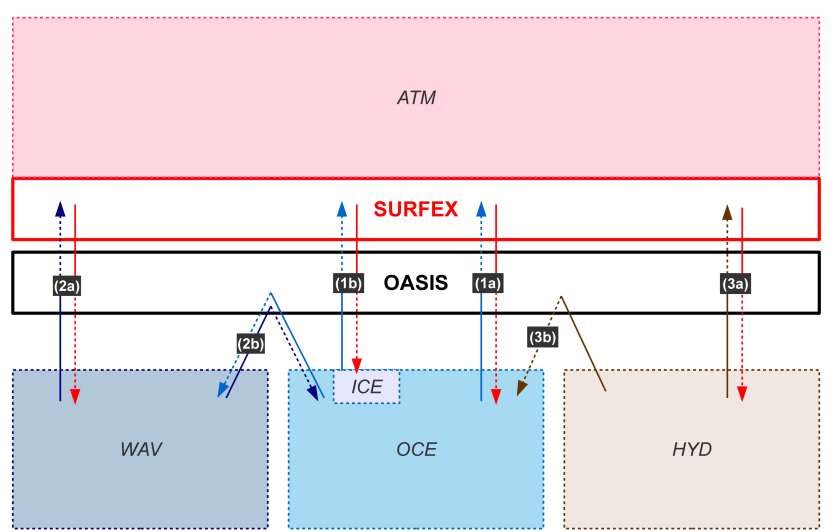

Figure 1. Flow chart of the SURFEX-OASIS coupling interface. An ocean model (OCE), possibly including a sea-ice model (ICE), a wave model (WAV) and a hydrological model (HYD), can exchange fields with the SURFEX interface (arrows 1a, 1b, 2a and 3a). Exchanges between OCE and WAV (and HYD) are also possible through OASIS (arrows $2 b$ and $3 b$ ). When using an ATM component, SURFEX is embedded in the ATM executable.

NEMO (Madec et al., 2008), SYMPHONIE (Marsaleix et al., 2008, 2009, 2012) or MARS3D (Lazure and Dumas, 2008) ocean models are coupled to SURFEX. In this paper, we do not discuss the hard-coded exchanges between SURFEX and the ATM component, as they are not done through OASIS3MCT; these are described in detail in Masson et al. (2013).

\subsubsection{OCE-ICE-SURFEX}

In Eq. (1), the term $F_{\text {ocean }}$ refers to the exchanges of heat, water and momentum between the atmosphere and the ocean. These exchanges are expressed as the net solar heat flux $\left(Q_{\text {sol }}\right)$, the non-solar heat flux $\left(Q_{\mathrm{ns}}\right)$, the freshwater flux $\left(F_{\text {wat }}\right)$ and the wind stress $(\tau)$. The fluxes at the air-sea interface are computed within SURFEX taking into account near-surface atmospheric and oceanic parameters, following a radiative scheme and a bulk parameterization.

$$
\begin{aligned}
Q_{\text {sol }} & =(1-\alpha) S_{W_{\text {down }},} \\
Q_{\mathrm{ns}} & =L_{W_{\text {down }}}-\varepsilon \sigma T_{\mathrm{S}}^{4}-H-L_{E}, \\
F_{\text {wat }} & =E-P_{L}-P_{S}, \\
\boldsymbol{\tau} & =\rho C_{\mathrm{D}}\left(\boldsymbol{U}_{\mathrm{s}}-\boldsymbol{U}_{\mathrm{a}}\right),
\end{aligned}
$$

where $S_{W_{\text {down }}}$ and $L_{W_{\text {down }}}$ are the incoming short-wave (solar) and long-wave (infrared) radiative heat fluxes, respectively. The sensible heat flux $(H)$, the latent heat flux $\left(L_{E}\right)$ and the momentum flux (or wind stress) are calculated thanks to a sea surface turbulent flux bulk parameterization. They depend on the wind speed and air-sea gradients of temperature, humidity and velocity, respectively. $\alpha$ is albedo, $\varepsilon$ is emissivity and $\sigma$ is the Stefan-Boltzman constant. Emissivity is a constant value, usually taken as 0.96 over the ocean. Ocean albedo can be taken as a constant or can evolve following the Taylor et al. (1996) formulation to account for the solar zenith angle, the Séférian et al. (2017) multi-spectral band albedo accounting for solar zenith angle and wind speed, or the Salisbury et al. (2013) formulation.

$\mathrm{E}$ is total evaporation (including sublimation), and $P_{\mathrm{L}}$ and $P_{\mathrm{S}}$ are liquid and solid precipitation on the surface, respectively (coming directly from the ATM component or from the atmospheric forcing in forced mode). $\boldsymbol{U}_{\mathrm{a}}$ is the wind at the first atmospheric level, $C_{\mathrm{D}}$ the drag coefficient calculated by the sea surface turbulent flux parameterization and $\rho$ the air density.

$T_{\mathrm{S}}$ and $\boldsymbol{U}_{\mathrm{s}}$ are the ocean surface temperature and horizontal current. They are here the only oceanic parameters needed to compute the air-sea exchanges, and thus transferred from OCE to SURFEX. In return, SURFEX transfers the sea surface flux values $Q_{\text {sol }}, Q_{\mathrm{ns}}, F_{\text {wat }}$ and $\boldsymbol{\tau}$ to the OCE component via OASIS3-MCT (Table 1).

Almost the same principles apply for the exchanges in the presence of sea ice. In this case, SURFEX needs the sea-ice cover $\left(c_{\text {ice }}\right)$ from the ocean model and calculates fluxes as

$F_{\text {ocean }}=\left(1-c_{\text {ice }}\right) F_{\mathrm{o}}+c_{\text {ice }} F_{\text {ice }}$,

where $F_{\mathrm{o}}$ is the flux over the open ocean calculated using the ocean properties and $F_{\text {ice, }}$, the sea-ice flux, is calculated using the Charnock (1955) flux formulation. In this case, the radiative fluxes are calculated using the sea-ice temperature, albedo and emissivity. Emissivity is taken as constant over sea ice, whereas albedo and surface temperature are given by the ocean and sea-ice model. In summary, in the presence of sea ice, SURFEX needs the sea-ice temperature, albedo and ice cover in addition to the free ocean parameters usually needed. In return, SURFEX transfers the area-averaged sea-ice and open ocean momentum, heat and water flux to the OCE and ICE components, respectively (Table 1). These mixed fluxes allow us to conserve energy and water in the coupling. However, SURFEX also calculates and sends pure sea-ice fluxes to the ICE component. These fluxes will be used in the ICE component to redistribute the total fluxes over ice categories and open ocean, in a conservative way. In the coupled models already developed, the ICE component is embedded in the OCE model, but technically they could run separately. The main challenge in running OCE and ICE separately using OASIS3-MCT is more on how to deal with energy conservation when sea-ice fraction changes.

Note here that thanks to the tiling approach used in SURFEX, the fluxes sent to OCE are pure ocean fluxes ( $F_{\text {ocean }}$ in Eq. 1) without any effect from land surface fluxes over coastal grid points. Accordingly, in the grids' file provided automatically by the SURFEX PREP tool, the area corresponding to the ocean flux ( $\left.\mathrm{A}=A_{\text {ocean }}\right)$ over coastal grid cells is calculated as

$A_{\text {ocean }}=c_{\text {ocean }} A_{\text {gridcell }}$ 
where $A_{\text {gridcell }}$ corresponds to the atmospheric grid cell area, so as to correctly calculate weights for conservative interpolation.

\subsubsection{WAV-SURFEX-OCE}

In the formalism of fluxes between the ocean and the atmosphere presented in the former section, the fluxes do not necessarily depend on the presence of ocean waves. However, waves modify the sea surface roughness and consequently the drag coefficient $C_{\mathrm{D}}$ of Eq. (5). In SURFEX, the atmosphere momentum flux can vary in function of sea state through the drag coefficient $C_{\mathrm{D}}$ depending on the roughness length $z_{0}$ as

$C_{\mathrm{D}}=\frac{K^{2}}{\left(\log \left(\frac{z_{\mathrm{a}}}{z_{0}}\right)-\psi\left(\frac{z_{\mathrm{a}}}{L}\right)\right)^{2}}$

where $z_{\mathrm{a}}$ is the height of the first atmospheric level, $K$ the von Kàrmàn constant, $\psi$ an empirical stability function, and $L$ the Monin-Obukhov length. The roughness length $z_{0}$ is related to the Charnock parameter $\alpha$ and to the friction velocity $u_{*}$ through Charnock's formulation (1955), with the smooth flow limit effect following Smith (1988):

$z_{0}=\alpha \frac{u_{*}^{2}}{g}+0.11 \frac{v}{u_{*}}$,

where $v$ is the kinematic viscosity of dry air and $g$ the gravity acceleration.

The parameterization of the wave effect into the surface atmospheric boundary layer remains an open question and thus two different approaches were implemented in SURFEX to represent the effect of waves on $z_{0}$ :

1. as in the ECMWF operational coupled IFS-WAM (Janssen et al., 2001), the Charnock parameter $\alpha$ is directly computed in WAV as a function of the sea state, and then transferred to SURFEX and used to compute the roughness length and the drag coefficient using Eqs. (8) and (9).

2. the wave parameters $H_{\mathrm{S}}$ and $T_{\mathrm{p}}$ are computed in WAV, and then transferred to SURFEX and used to compute the Charnock parameter using the COARE 3.0 bulk flux algorithm (Fairall et al., 2003). Two different wavedependent methods are available within COARE 3.0, making the roughness length dependent on either the peak period of the waves only (Eq. 10, from Oost et al., 2002) or on both the peak period and the significant wave height (Eq. 11, from Taylor and Yelland, 2001).

$$
\begin{gathered}
\alpha=50\left(\frac{c_{\mathrm{p}}}{u_{*}}\right)^{-2.5}, \\
z_{0}=1200 H_{\mathrm{S}}\left(\frac{H_{\mathrm{S}}}{L_{P}}\right)^{4.5},
\end{gathered}
$$

where $c_{\mathrm{p}}$ is the wave-phase velocity and $L_{p}$ the wave length. In open ocean conditions, these two quantities can be related to the peak period using standard deep-water gravity wave relationships:

$L_{P}=\frac{g T_{\mathrm{P}}^{2}}{2 \pi} ; c_{\mathrm{P}}=\frac{g T_{\mathrm{P}}}{2 \pi}$.

The first approach relies on the wave model computation of the Charnock coefficient that is known to be very sensitive to the high-frequency tail of the spectrum, which is generally parameterized. The second approach allows us to compare more directly the wave parameter coupling fields with observations. Both approaches can be used in the SURFEXWAV coupling through the choice of specific parameters in the SURFEX namelist.

To summarize, SURFEX receives (via OASIS3-MCT) wave parameters like the significant height $\left(H_{\mathrm{S}}\right)$, the wave peak period $\left(T_{\mathrm{p}}\right)$, and the Charnock parameter $(\alpha$; Charnock, 1955) from WAV, while it sends to WAV (via OASIS3-MCT) the atmospheric wind speed $\left(U_{\mathrm{a}}\right)$ as a direct forcing for the waves.

The exchanges between OCE and WAV components (Fig. $1(2 b)$ ) are directly managed by OASIS3-MCT and are thus independent of the SURFEX interface. They are summarized here to fully describe the WAV-SURFEX-OCE coupled system (see also Table 1) even if it is not directly within the scope of the present paper. Surface waves induce Stokes drift, which impacts the oceanic dynamics and the advection of the tracers. These are provided to the ocean model as surface Stokes drift (USS) and Stokes transport (TUS; e.g. Breivik et al., 2014) computed by WAV. The additional pressure associated with waves, namely the wave-induced Bernoulli head pressure (BHD), is also provided by WAV as well as the net wave-supported stress (TAW). This last term corrects the wind stress simulated by the atmospheric model from the part forcing the wave dynamics. The increase in ocean mixing due to wave breaking is represented by the wave-toocean turbulent kinetic energy flux (FOC). At the sea surface, momentum from breaking waves (the wave ocean momentum flux, TWO) is a source of ocean momentum. Likewise, the dissipation of the waves in the ocean boundary layer increases mixing (the corresponding energy flux due to bottom friction is FBB) and is also a source of ocean momentum (represented by the momentum flux due to bottom friction, TBB). Lastly, the increase in the bottom friction due to the wave is represented as a function of the current and the root mean square amplitude of the orbital velocity induced by the waves (UBR). Finally, the significant wave height $\left(H_{\mathrm{S}}\right)$ is 
Table 1. List of exchanged fields (see flow chart in Fig. 1).

\begin{tabular}{|c|c|c|}
\hline Annotation & $\begin{array}{l}\text { SOURCE model to TARGET model } \\
\text { field description }\end{array}$ & Name in SURFEX namelist \\
\hline (1a) & OCE to SURFEX & \\
\hline$T_{\mathrm{S}}$ & Sea surface temperature & CSEA_SST \\
\hline$U_{\mathrm{s}}, V_{\mathrm{s}}$ & $\begin{array}{l}\text { Zonal and meridional sea surface current } \\
\text { SURFEX to OCE }\end{array}$ & CSEA_UCU, CSEA_VCU \\
\hline$\tau_{u}, \tau_{v}$ & Zonal and meridional wind stress & CSEA_FWSU, CSEA_FWSV \\
\hline$Q_{\mathrm{ns}}$ & Non-solar net heat flux & CSEA_HEAT \\
\hline$Q_{\text {sol }}$ & Solar net heat flux & CSEA_SNET \\
\hline$U$ & Near surface wind speed & CSEA_WIND \\
\hline$\tau$ & Wind stress module & CSEA_FWSM \\
\hline$E$ & Evaporation & CSEA_EVAP \\
\hline$P_{\mathrm{L}}$ & Liquid precipitation & CSEA_RAIN \\
\hline$P_{\mathrm{S}}$ & Solid precipitation & CSEA_SNOW \\
\hline$F_{\text {wat }}$ & Net water flux (Eq. 4) & CSEA_WATF \\
\hline$P_{\text {surf }}$ & Surface pressure & CSEA_PRES \\
\hline (1b) & ICE to SURFEX & \\
\hline$T_{\text {sice }}$ & Sea-ice temperature & CSEAICE_SIT \\
\hline$C_{\text {ice }}$ & Sea-ice cover & CSEAICE_CVR \\
\hline$\alpha_{\text {ice }}$ & $\begin{array}{l}\text { Sea-ice albedo } \\
\text { SURFEX to ICE }\end{array}$ & CSEAICE_ALB \\
\hline$Q_{\mathrm{ns}}$ & Non solar net heat flux over sea ice & CSEAICE_HEAT \\
\hline$Q_{\text {sol }}$ & Solar net heat flux over sea ice & CSEAICE_SNET \\
\hline$E_{\mathrm{S}}$ & Sublimation & CSEAICE_EVAP \\
\hline$(2 a)$ & WAV to SURFEX & \\
\hline$H_{\mathrm{S}}$ & Significant wave height & CWAVE_HS \\
\hline$T_{\mathrm{p}}$ & Peak period & CWAVE_TP \\
\hline$\alpha$ & Charnock coefficient & CWAVE_CHA \\
\hline$U_{\mathrm{s}}, V_{\mathrm{s}}$ & $\begin{array}{l}\text { Zonal and meridional sea surface current } \\
\text { SURFEX to WAV }\end{array}$ & CWAVE_UCU,CWAVE_VCU \\
\hline $\begin{array}{l}U_{10}, V_{10} \\
(2 \mathrm{~b})\end{array}$ & $\begin{array}{l}\text { Zonal and meridional } 10 \mathrm{~m} \text { wind speed } \\
\text { WAV to OCE }\end{array}$ & CWAVE_U10, CWAVE_V10 \\
\hline$H_{\mathrm{S}}$ & Significant wave height & - \\
\hline $\mathrm{USS}_{X}, \mathrm{USS}_{Y}$ & Zonal and meridional surface Stokes drift & - \\
\hline $\operatorname{TUS}_{X}, \operatorname{TUS}_{Y}$ & Zonal and meridional Stokes transport & - \\
\hline BHD & Wave-induced Bernoulli head pressure & \\
\hline TAW $_{X}$, TAW $_{y}$ & Zonal and meridional net wave supported stress & - \\
\hline TWO $_{X}$, TWO $_{Y}$ & Zonal and meridional wave ocean momentum flux & - \\
\hline FOC & Wave to ocean turbulent kinetic energy flux & - \\
\hline $\mathrm{TBB}_{X}, \mathrm{TBB}_{Y}$ & $\begin{array}{l}\text { Zonal and meridional wave boundary } \\
\text { layer momentum flux }\end{array}$ & - \\
\hline FBB & Wave boundary layer turbulent kinetic energy flux & - \\
\hline UBR & $\begin{array}{l}\text { Root mean square amplitude of the orbital velocity } \\
\text { of the waves } \\
\text { OCE to WAV }\end{array}$ & - \\
\hline SSH & Sea surface height & - \\
\hline $\begin{array}{l}U_{\mathrm{s}}, V_{\mathrm{s}} \\
(3 \mathrm{a})\end{array}$ & $\begin{array}{l}\text { Zonal and meridional sea surface current } \\
\text { HYD to SURFEX }\end{array}$ & - \\
\hline WTD & Water table depth & CWTD \\
\hline$C_{\mathrm{WTD}}$ & Grid-cell fraction of water rise & CFWTD \\
\hline$C_{\mathrm{FP}}$ & Flood plains fraction & CFFLOOD \\
\hline$W_{\mathrm{FP}}$ & $\begin{array}{l}\text { Flood plains potential infiltration } \\
\text { SURFEX to HYD }\end{array}$ & CPIFLOOD \\
\hline$R_{\mathrm{nf}}$ & Surface runoff & CRUNOFF \\
\hline$D_{\mathrm{r}}$ & Deep drainage & CDRAIN \\
\hline$F_{\text {CALV }}$ & Calving flux & CCALVING \\
\hline$F_{\mathrm{WFP}}$ & Flood plains net upward water flux & CSRCFLOOD \\
\hline$(3 b)$ & HYD to OCE & \\
\hline$D_{\text {is }}$ & Coastal runoff & CRIVDIS \\
\hline$F_{\mathrm{CGR}}$ & Greenland calving & CCALVGRE \\
\hline$F_{\mathrm{CAN}}$ & Antarctic calving & CCALVANT \\
\hline
\end{tabular}


also used to define the vertical extent of the wave effects. All the variables are sent from WAV to OCE through OASIS3MCT. In return, OCE sends to WAV (Fig. $1(2 b)-$ OCE to WAV) the sea surface height ( $\mathrm{SSH}$ ) and the surface currents $\left(\boldsymbol{U}_{\mathrm{s}}\right)$.

\subsubsection{HYD-SURFEX-OCE}

Originally, several embedded couplings of SURFEX with hydrological models were developed at CNRM, e.g. with the Total Runoff Integrating Pathways (CTRIP) River Routing Model at the global scale (Decharme et al., 2010), the MODCOU hydrogeological model over France (Habets et al., 2008), and the TOPography based MODEL (TOPMODEL) hydrological model at the mesoscale (Bouilloud et al., 2009). As hydrological models are 2-D models with specific grids, these implementations were hard-coded and based on specific grid types. In order to ease the upgrade of the hydrological model in these coupled configurations, it was decided to implement the hydrological coupling in the standard coupling interface, using the CTRIP hydrological model as a reference.

Hydrological models are used to compute three processes: groundwater dynamics, river runoffs and discharges to the ocean. Some of the hydrological models, such as CTRIP, also simulate floodplains. These processes are strongly coupled to the land surface water and energy budget, and feedback to the ocean. For this purpose, the CTRIP river routing model has been coupled to SURFEX via OASIS3-MCT.

In SURFEX, the continental water and energy budgets are computed using the ISBA scheme. The soil moisture and heat vertical transports are explicitly solved using a multi-layer scheme (Boone et al., 2000; Decharme et al., 2011). This scheme has been validated over many local field datasets (Boone et al., 2000; Habets et al., 2003; Decharme et al., 2011) or regional studies (Decharme et al., 2013, 2016), improving confidence in the model's ability to consistently represent a variety of environmental conditions in different climate regimes. It includes a comprehensive sub-grid hydrology to account for the heterogeneity of precipitation, topography and vegetation in each grid cell (Decharme and Douville 2006; Decharme et al., 2013).

SURFEX sends to CTRIP the surface runoff $\left(R_{\mathrm{nf}}\right)$ and the deep soil drainage $\left(D_{\mathrm{r}}\right)$ calculated in ISBA, as well as the freshwater flux to the atmosphere over floodplain open water ( $F_{\text {WFP }}$, Decharme et al., 2012). The deep soil drainage represents the infiltration of water that is directly routed to the ocean in the absence of groundwater in the grid cell.

Concerning the groundwater, CTRIP in turn sends to SURFEX the water table depth (WTD) of the groundwater, i.e. the depth of the groundwater, and the grid-cell groundwater fraction $\left(C_{\text {WTD }}\right)$. In other words, the WTD computed in CTRIP acts as the lower boundary condition for the ISBA soil moisture diffusive equation (Vergnes et al., 2014). For the floodplains, CTRIP sends to SURFEX the floodplain grid-cell fraction $\left(C_{\mathrm{FP}}\right)$ and the floodplain water mass flux to the land surface reservoir $\left(W_{\mathrm{FP}}\right)$. Finally, CTRIP sends to the oceanic model the discharges at the mouths of all rivers $\left(D_{\text {is }}\right)$.

\section{Multi-model and multi-scale applications}

The new interface allows us to couple all atmospheric models that integrate SURFEX to ocean, ice, hydrology, and wave models, whatever the domain, resolution, and coupling time step are. In this section, several examples of such coupled models (Fig. 2) are presented to illustrate the capabilities of the SURFEX standard coupling interface and to sample the different types in terms of coupled components. They are listed in Table 2, together with their domain size and integration duration and the SURFEX version used.

The CNRM-CM global climate model and its regional counterpart, CNRM-RCSM, are updated versions of former coupled climate modelling systems. This has allowed us to validate the new coupling interface by comparing it to these former coupled ATM-OCE systems. The regional version of the climate model was also a technical test bed to check the validity of the coupling in the case of limited-area models. In the following, we thus illustrate first the global and regional climate-scale applications using CNRM-CM and -RCSM, and then new coupled systems based on the same interface but using different domain sizes, and different ocean and atmospheric models and/or regions. These new systems were developed to address various scientific questions mainly on shorter timescales (from hours to days).

Table 2 also provides information on the relative computational cost of the components for the different coupled systems. In most cases, the ocean model uses less than $25 \%$ of the coupled system total number of cores. One exception is the MESONH-NEMO Indian Ocean, for which the ocean model uses about $40 \%$ of the total cores. For this last case, it should be stressed that no optimization regarding the balance of the two model components was done; improving this balance using the lucia tool distributed with OASIS3-MCT_3.0 should enhance greatly the performance of the coupled system, as has been the case for the other coupled systems.

The relative cost of using OASIS3-MCT has not been systematically evaluated for all configurations presented here. For example, the cost of OASIS3-MCT interpolations for the CNRM-CM global climate model is evaluated to less than $2 \%$ of the model elapsed time. The benefit of using OASIS3MCT instead of OASIS3 has not been precisely documented for our configurations as it came with new component models with increased scalability running on a higher number of cores. However, separate performance evaluation has shown that OASIS3-MCT is much more efficient than the previous sequential OASIS3 version. Figure 4 in Craig et al. (2017) shows that the time for a back-and-forth coupling exchange between a T799 grid (i.e. a global atmospheric gaussian reduced grid with 843490 grid points) and an ORCA025 grid 
Table 2. List of model configurations implemented, with their domain size and their computational balance.

\begin{tabular}{|c|c|c|c|c|c|c|c|c|}
\hline ATM model & OCE model & $\begin{array}{l}\text { WAV or HYD } \\
\text { model }\end{array}$ & $\begin{array}{l}\text { SURFEX } \\
\text { version }\end{array}$ & $\begin{array}{r}\text { Domain } \\
\text { size }(k m)\end{array}$ & $\begin{array}{l}\text { Integration } \\
\text { duration }\end{array}$ & $\begin{array}{l}\text { ATM no. } \\
\text { of cores }\end{array}$ & $\begin{array}{l}\text { OCE no. } \\
\text { of cores }\end{array}$ & $\begin{array}{r}\text { HYD or WAV } \\
\text { no. of cores }\end{array}$ \\
\hline ARPEGE-Climat & NEMO-GELATO & CTRIP (HYD) & $\mathrm{v} 8.0$ & global & centuries & 384 & 127 & 1 \\
\hline ALADIN-Climat & NEMO MED & CTRIP (HYD) & $\mathrm{v} 8.0$ & $\sim 5000$ & $\begin{array}{l}\text { decades to } \\
\text { centuries }\end{array}$ & 240 & 21 & 1 \\
\hline AROME WMED & NEMO WMED36 & & v7.2 & $\sim 2000$ & days & 96 & 4 & \\
\hline MESO-NH & SYMPHONIE & & v7.3 & $\sim 2000$ & days & 1024 & 156 & \\
\hline MESO-NH & NEMO Indian Ocean & & v7.3 & $\sim 1000$ & hours to days & 16 & 12 & \\
\hline MESO-NH & MARS3D & $\begin{array}{l}\text { WAVEWATCH3 } \\
\text { (WAV) }\end{array}$ & v7.3 & $\sim 150$ & hours to days & 20 & 7 & 5 \\
\hline
\end{tabular}

(i.e a tripolar grid with $1442 \times 1021$ grid points) is about an order of magnitude smaller in OASIS3-MCT for a large range of core counts.

As already stated, some groups have worked with different SURFEX versions since they were compelled to the version already used in their well-validated version of the atmospheric model (see Table 2).

\subsection{The CNRM-CM6 global climate configuration}

The CNRM-CM climate coupled model is designed to perform global atmosphere-ocean coupled integrations over centuries to millennia and is used to address many scientific questions related to the climate system. It is a state-of-the-art climate model that participates in the CMIP model intercomparison project. The newly designed model, CNRM-CM6, prepared for CMIP6, combines all the components pictured in Fig. 1, except WAV. It is based on the ARPEGE-Climat v6 atmospheric model at about $140 \mathrm{~km}$ resolution using SURFEX v8.0, the NEMO v3.6 ocean model and the GELATO v6 sea-ice model, both at $1^{\circ}$ nominal resolution, and the CTRIP river routing model at $0.5^{\circ}$ resolution. Figure 2a shows the orography and bathymetry of the atmosphere and ocean models. All components are coupled through OASIS3-MCT every hour. Before assembling the whole coupled system, the different components are tested in more constrained configurations. We illustrate in the following how the new coupling interface allows us to analyse the coupling of the different components step by step.

First, we assess the performance of the land surface model alone (SURFEX) driven by atmospheric forcings provided by Princeton University at $1^{\circ}$ resolution (Sheffield et al., 2006) over the period 1948-2010. Figure 3a shows the summer mean land surface evaporation averaged over the period (1980-2009). The zonal mean evaporation compares relatively well with the observed estimate from Jung et al. (2009). In this configuration, other variables can be assessed such as snow cover, soil temperature at specific sites in terms of mean annual cycle and interannual variability. This allows us to validate the intrinsic performance of the land surface parameterizations.
As a second step, we assess the performance of the whole continental hydrologic system (SURFEX-CTRIP) by coupling SURFEX with the CTRIP river model using the same atmospheric forcing. As described in Sect. 2.2.3, the surface and groundwater reservoirs exchange water with the rivers. From Fig. 3b, it can be seen that the coupling does not change the realism of the evaporation flux.

As a third step, the full land surface hydrology system is run online with the atmospheric model (ARPEGE-ClimatSURFEX-CTRIP) over the period 1978-2010. The land surface evaporation flux is impacted by the coupling with the atmospheric model (Fig. 3c): the high-latitude evaporation is overestimated due the radiative and precipitation biases of the atmospheric model. However, the global evaporation pattern remains realistic.

Finally, the full CNRM-CM6 system has been integrated over the period 1950-2010. In the full system, the simulated land evaporation realism is similar to the atmospheric simulation (Fig. 3d to compare with Fig. 3c). Generally, the different components of the CNRM-CM6 system are extensively validated against observations in terms of mean climate, variability at all timescales (from diurnal cycles to long-term trends) in stand-alone integrations as well as in fully coupled integrations.

\subsection{CNRM-RCSM6 over the Mediterranean Sea (ALADIN Climat-NEMOMED12-CTRIP)}

RCSMs belong to the same family as the GCMs used in the CMIP experiments, but have a higher resolution over a limited-area domain. The new CNRM-RCSM6 version presented here is the limited-area counterpart of CNRM-CM6. The ALADIN-Climate $v 6$ atmosphere model is the regional version of ARPEGE-Climate v6, and uses the same SURFEX v8.0 version. The resolution of the atmosphere grid is about $12 \mathrm{~km}$. The CTRIP model presented in Sect. 2.2.3 is also included, with a $0.5^{\circ}$ resolution. The ocean model is a limited-area version of NEMO for the Mediterranean basin (called NEMOMED12) at a resolution of about $6 \mathrm{~km}\left(1 / 12^{\circ}\right.$ grid; Beuvier et al., 2012; Hamon et al., 2016).

Figure $2 \mathrm{~b}$ shows the land-sea mask and orography of ALADIN-Climate and the bathymetry of NEMOMED12, as 
(a) CNRM-CM6

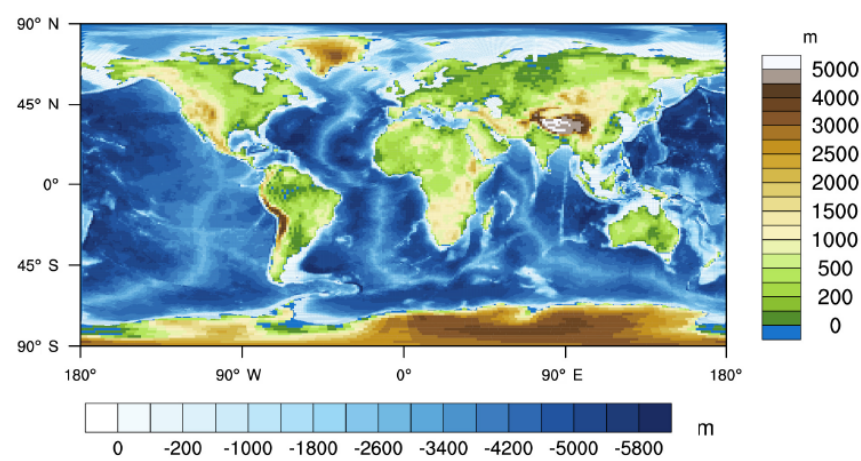

(c) AROME-NEMO WMED

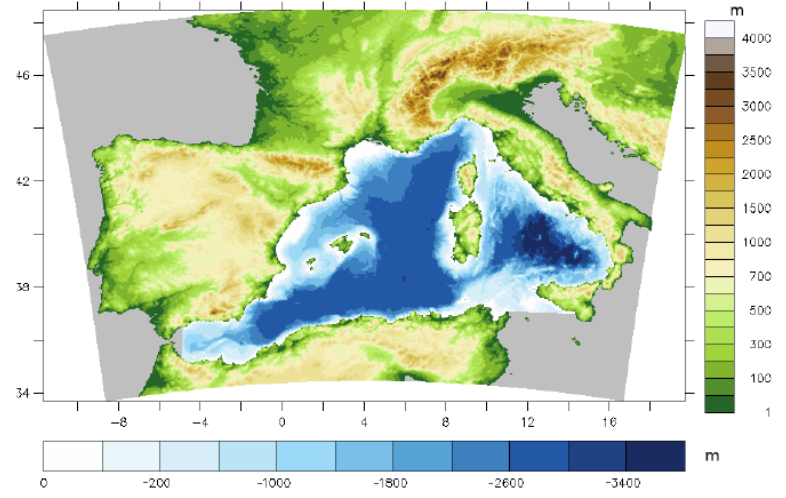

(e) MESONH-NEMO

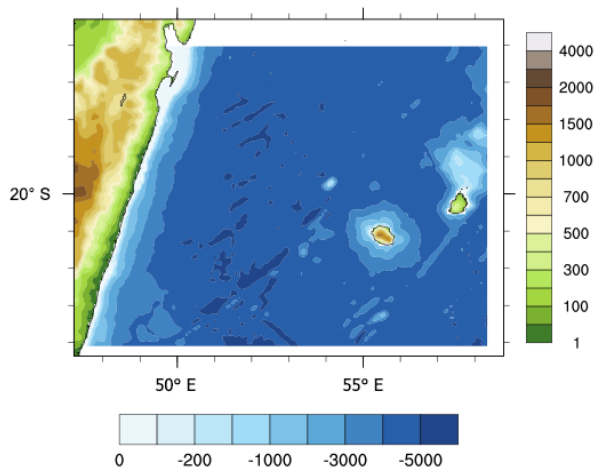

(b) CNRM-RCSM6

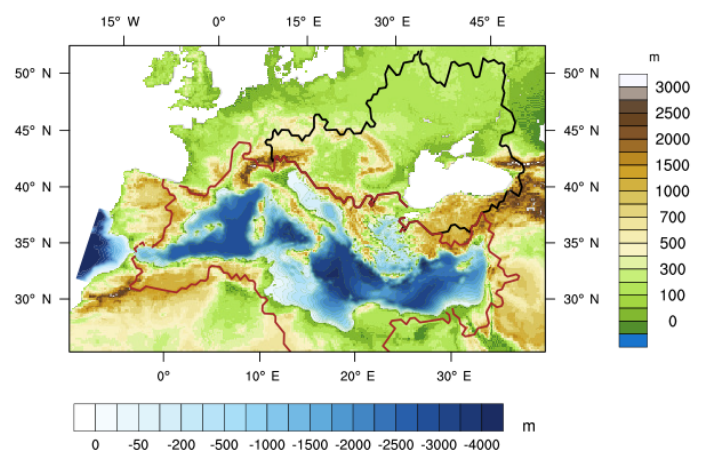

(d) MESONH-Symphonie

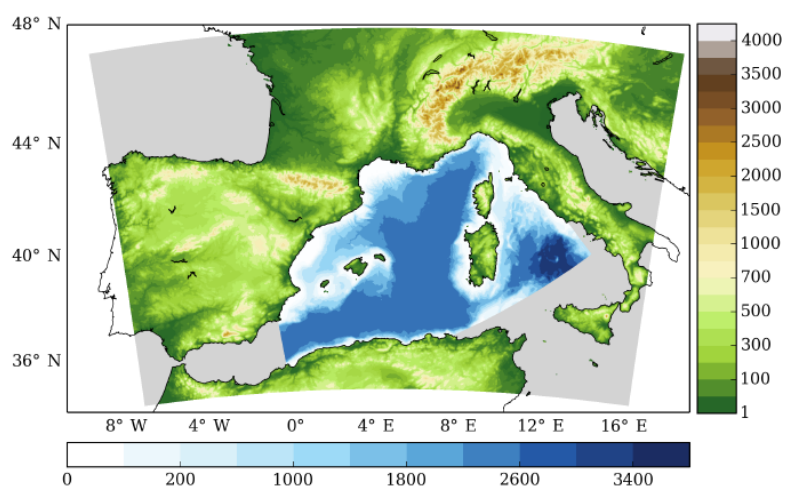

(f) MESONH-MARS3D-WW3

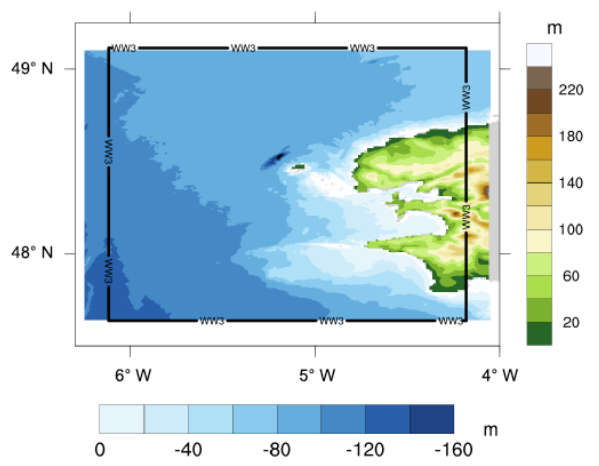

Figure 2. Domains of the coupled systems: topography (green colours) and bathymetry (blue colours) of the respective models (a) CNRMCM6, (b) CNRM-RCSM6, (c) AROME-NEMO WMED, (d) MESONH-Symphonie over the western Mediterranean Sea, (e) MESONHNEMO over the south-eastern Indian Ocean, and (f) MESONH-MARS3D-WAVEWATCH3 (Ouessant).

well as the limits of the watersheds that drain into the Black Sea (black contour) and into the Mediterranean Sea (red contour) and on which CTRIP is run. The atmosphere-ocean coupling frequency is $1 \mathrm{~h}$, so that the diurnal cycle of the ocean sea surface temperature (SST) can be simulated. To assess the realism of the SST diurnal cycle simulated by the model under present-day conditions, the model was run using reanalysis data at the lateral boundaries for the atmosphere and ocean components. ORAS4 is used as the Atlantic boundary condition for the ocean model (Balmaseda 
(a) SFX

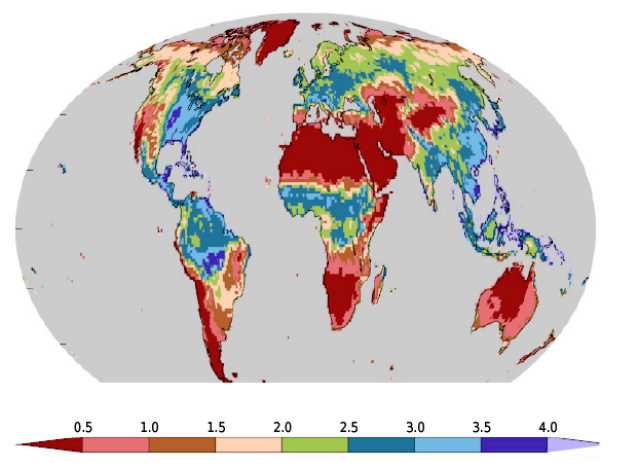

(c) SFX-CTRIP-ATM

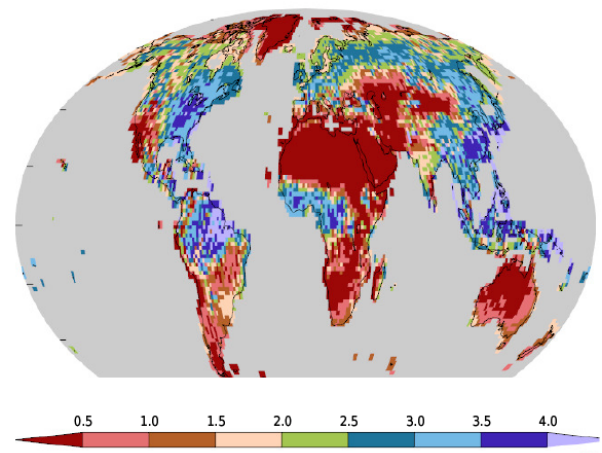

(b) SFX-CTRIP
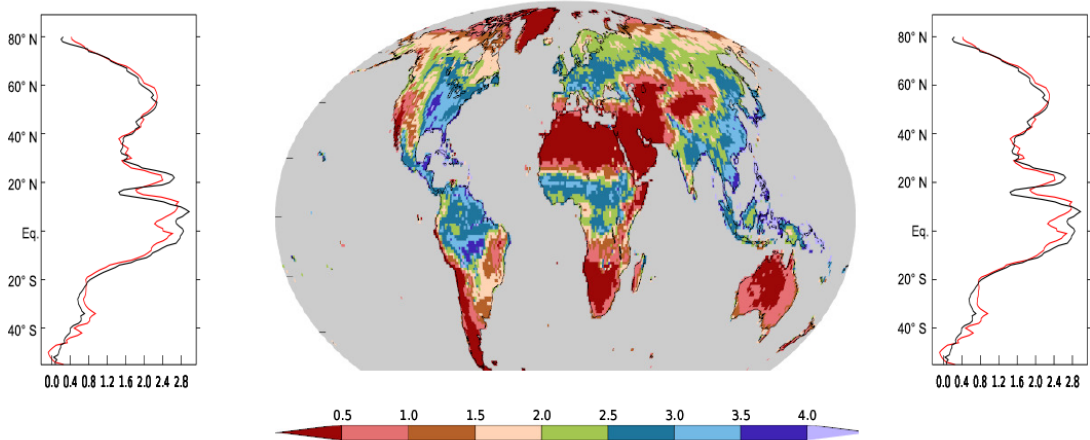

(d) SFX-CTRIP-ATM-OCE
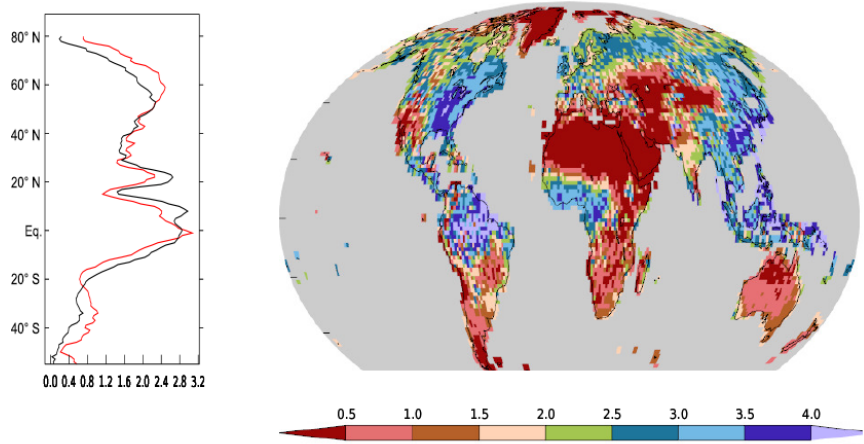

Figure 3. JJA mean land surface evaporation averaged over the period 1980-2009. In the zonal mean plot, the black line represents observationally derived data from Jung et al. (2009) averaged over 1982-2008, the red line the simulation.

et al., 2013) and the ERA-Interim reanalysis (Berrisford et al., 2009) is used for the atmosphere. Spectral nudging is applied in addition over the inner atmospheric model domain toward the ERA-Interim reanalysis. The solar penetration on the upper ocean is prescribed using monthly mean maps of chlorophyll-a concentration (Ocean Colour Climate Change Initiative dataset, European Space Agency, available online at http://www.esa-oceancolour-cci.org/).

The amplitude of the SST diurnal cycle simulated by the model is compared to the Météo-France Lion buoy observations in the north-western Mediterranean over the 20092013 period (Fig. 4). The amplitude of the diurnal cycle of the SST is computed as the difference between the maximum of the hourly mean SST, between 09:00 and 17:00 UTC, minus the minimum between 18:00 UTC the day before and 08:00 UTC. As a first estimation, we consider that we can compare the SST of the buoy (at $1 \mathrm{~m}$ depth, grid point nearest to the buoy) to the SST of the model (temperature of the $1 \mathrm{~m}$ thick first layer). Only amplitudes above $0.1^{\circ} \mathrm{C}$ are kept, and the results are split according to the season.

Considering that the model grid point cannot exactly reproduce the local buoy SST, these results show that CNRMRCSM6 represents a realistic diurnal cycle of the SST, though more or less close to the observations according to the season for the presented simulation with an overestimation in spring and summer and an underestimation in autumn. They allow us to enlarge the study of the links between airsea flux representation and the diurnal cycle.

\subsection{AROME-NEMO WMED}

This application gives an example of the new coupling of a NWP limited-area model to an ocean model over a fraction of its marine domain. The newly developed AROMENEMO coupled system aims at better representing the ocean-atmosphere coupled processes at a fine scale and at assessing the impact of the coupling on short-range forecast of severe weather in the Mediterranean region.

This coupled system combines the NEMO ocean model and the NWP system of Mété-France AROME which belongs to the common ARPEGE/ALADIN/AROME model software suite. There is no ICE, no WAV and no HYD component. It is applied over the western Mediterranean Sea (Fig. 2c) and involves, as an ATM model, the $2.5 \mathrm{~km}$ resolution AROME-WMED configuration (Fourrié et al., 2015) in version cy38t1. Its surface scheme is SURFEX v7.2. The 

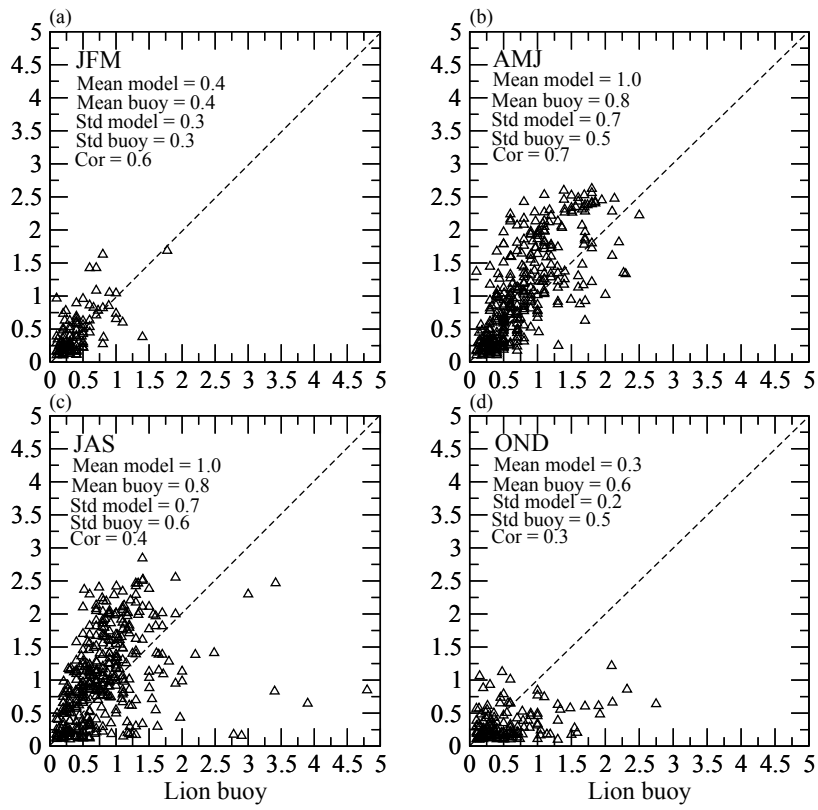

Figure 4. Amplitude in ${ }^{\circ} \mathrm{C}$ of the 2009-2013 SST diurnal cycle for the Lion buoy ( $x$-axis) and the model simulation ( $y$-axis), according to the season: (a) JFM, (b) AMJ, (c) JAS and (d) OND. Only values above $0.1^{\circ}$ are kept. Mean values and standard deviations are given for each season, as well as the daily temporal correlation.

OCE model is NEMO v3.2 in the WMED36 configuration $\left(1 / 36^{\circ}\right.$ resolution; Lebeaupin Brossier et al., 2014). The coupling impact is shown for Intense Observation Periods (IOPs) 13 and 16b of HyMeX (Ducrocq et al., 2014). For the coupled experiment, called CPL, the ATM initial and lateral boundary conditions come each day, respectively, from the AROME-WMED analysis at 00:00 UTC and from the $10 \mathrm{~km}$ resolution ARPEGE operational forecasts. The OCE initial conditions come from a former ocean-only WMED36 simulation and the PSY2V4R4 analyses (Lellouche et al., 2013) are used as open-boundary conditions. CPL runs for a $48 \mathrm{~h}$ range each day starting at 00:00 UTC, with OCE restarted each time from the previous run $\left(t_{0}+24 \mathrm{~h}\right.$ of the previous day). The coupling frequency is $1 \mathrm{~h}$ and the interpolation method is bilinear. The Atlantic Ocean, the Adriatic Sea and the western Ionian Sea are uncoupled (grey zones in Fig. 2c). CPL is compared to an atmosphere-only simulation called ARO, with the same ATM and SST initial fields as CPL, but with the SST not evolving during the run.

Figure 5 compares CPL and ARO at the Lion buoy location $\left(4.7^{\circ} \mathrm{E}, 42.1^{\circ} \mathrm{N}\right)$ along with the forecasts starting at 00:00 UTC on 12 and 13 October 2012 (IOP13) and on 26 and 27 October 2012 (IOP16b). The time evolution of SST in CPL follows the observed evolution well, with a cooling in response to the abrupt wind speed increase during IOP16b of about $2.5^{\circ} \mathrm{C}$ compared to $3.5^{\circ} \mathrm{C}$ in the observations (Fig. 5b). The SST from ARO is constant and thus overestimated and, as a consequence, the latent heat flux (LE) is larger by more than $150 \mathrm{~W} \mathrm{~m}^{-2}(\sim 15 \%)$ on 28 October. The differences for IOP13 are weaker on average (Fig. 5a). Some differences are seen for the precipitation rate on 14 and 26 October. The low-level wind and temperature are close in the two experiments and in agreement with observations, especially for short-range $(0-24 \mathrm{~h})$ forecasts. So, the impact of the interactive coupled ocean can be significant for intense weather situations with abrupt changes in the wind speed and/or in the surface fluxes, especially for longer-term forecasts (24-48 h; Rainaud et al., 2017). Further investigations are ongoing to evaluate the coupled processes' impact on other case studies.

\subsection{MESONH-SYMPHONIE}

This example and the following one represent applications of the coupling interface between the MESONH research atmospheric model and various OCE models. The MESONHSYMPHONIE coupled system was developed to investigate the role of air-sea interactions in the regional and coastal hydrodynamics of the north-western Mediterranean.

For this application, the coupled system was used at high resolution: $2.5 \mathrm{~km}$ for the MESONH v5.2 convectionpermitting atmospheric model with SURFEX v7.3 and $1 \mathrm{~km}$ for the SYMPHONIE eddy-resolving ocean model. As shown in Fig. 2d, the atmospheric numerical domain is wider than the oceanic domain. Outside the oceanic domain (grey marine zones in Fig. 2d), fluxes are classically computed using OSTIA SST analysis (Donlon et al., 2012) at a spatial resolution of $6 \mathrm{~km}$. In the coupled simulation (CPL), the coupling frequency is set to $600 \mathrm{~s}$ and a bilinear interpolation is used. The uncoupled ocean-only simulation (UNCPL) is a twin experiment in which air-sea fluxes are everywhere computed from OSTIA SST and provided to the ocean model at the same frequency and with the same interpolation as in the coupled simulation. The initial state is obtained by interpolation of a low-resolution coupled simulation described in Seyfried et al. (2017).

The impact of air-sea coupling on the heat-flux budget was carefully examined by comparing coupled and uncoupled simulations in the context of HyMeX. Figure 6 illustrates the results obtained with a 5-day simulation focusing on HyMeX IOPs 16a (25-27 October, southern wind and heavy precipitation over the French coasts) and 16b (2729 October, strong northerly wind). From IOPs 16a to $16 \mathrm{~b}$, the veering and intensification of the wind led to a strong increase in the non-solar heat flux over the Gulf of Lion. The OSTIA SSTs of the UNCPL simulation are very smooth and do not capture the mesoscale and sub-mesoscale oceanic structures (fronts, eddies, filaments) present in the CPL simulation. These oceanic structures significantly influence the spatial distribution of the flux. Furthermore, the results obtained for IOP $16 \mathrm{~b}$ suggest that the lack of coupling leads to a strong overestimation of the heat flux in an area which is critical for the pre-conditioning of deep ocean convection 

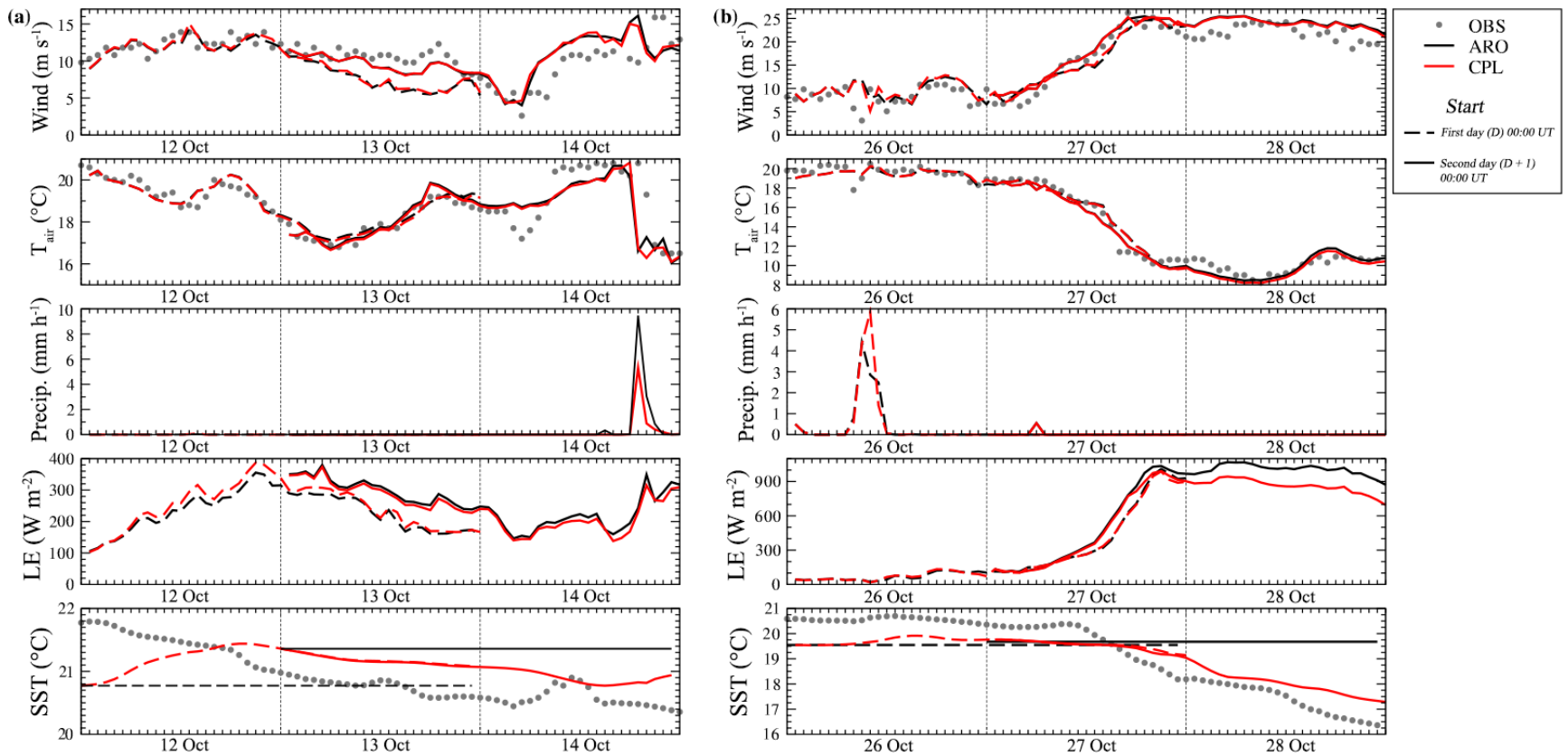

Figure 5. Time series of wind (first row), temperature at the first atmospheric level (second row), surface precipitation rate (third row), latent heat flux (fourth row) and SST (fifth row) at the LION buoy in CPL (red line) and ARO (black line) during (a) IOP13 (forecasts of 12 October 2012) and (b) IOP16b (forecasts of 26 and 27 October 2012), compared to in situ observations when available.

(Marshall and Schott, 1999). Further investigations are going on to better understand the role of the coupling in the frontal dynamics and to study its impact on ocean stratification and later evolution of convection.

\subsection{MESONH-NEMO Indian Ocean}

The MESONH-NEMO coupled system aims at better understanding and representing mesoscale ocean-atmosphere coupled processes over the Indian Ocean, with a particular focus on their role in tropical cyclone development and air-sea fluxes in extreme wind conditions.

This coupled system combines MESONH v5.1.4, integrating SURFEX v7.3 and NEMO v3.6. There is no ICE, no WAV, and no HYD component. The horizontal resolution of MESONH is $8 \mathrm{~km}$ and NEMO uses a $1 / 12^{\circ}$ resolution grid (i.e. around $9 \mathrm{~km}$ horizontal resolution; Fig. 2e). Initial atmospheric conditions come from the AROME-INDIEN analysis (a research version of AROME over the south-western Indian Ocean), atmospheric lateral boundary conditions from ECMWF analyses, and initial and boundary conditions for the ocean from the PSY4V2R2 analysis from CMEMS (E.U. Copernicus Marine Environment Monitoring Service).

Two simulations of tropical cyclone Bejisa, which passed very close to La Reunion island between 1 and 3 January 2014, are performed: a reference simulation, called NOCPL, in which only the atmospheric model is run, and a second one, called CPL, in which the coupled system is run with a $1 \mathrm{~h}$ coupling frequency. The simulated trajectory of Bejisa is quite similar in both simulations and very close to the best track at all times (not shown). This is consistent with the fact that the tropical cyclone trajectory is mainly driven by the large-scale dynamics. However, there are differences in the simulation of the microphysical structure of the cyclone, as illustrated in Fig. 7, which shows the integrated total water content (ITWC in millimetres) after $18 \mathrm{~h}$ and $30 \mathrm{~h}$ of simulations for the two simulations. After $30 \mathrm{~h}$, both the region of maximum ITWC and its intensity are different. This is still ongoing work, the next step being to increase the horizontal resolution for the atmosphere to resolve explicitly the microphysics and to study in more detail the impact of the oceanic coupling on the microphysical structure of tropical cyclones.

\subsection{MESONH-MARS3D-WAVEWATCH III}

This application implements the coupling interface for both an ocean model and a wave model. The MESONHMARS3D-WW3 (M2W) coupled system aims at studying the ocean-atmosphere-wave interactions at very fine horizontal scales (from $100 \mathrm{~m}$ to a few kilometres). Here the focus is over the Iroise Sea, which is characterized by a strong tidal current named Fromveur with an intensity of up to $2 \mathrm{~m} \mathrm{~s}^{-1}$, an intense SST seasonal front from April to October named the Ushant Front and waves coming with a large fetch.

The M2W system couples the MESONH atmospheric model, the MARS3D (Model for Application at Regional Scale) oceanic model and the WAVEWATCH III (hereafter 
(a)

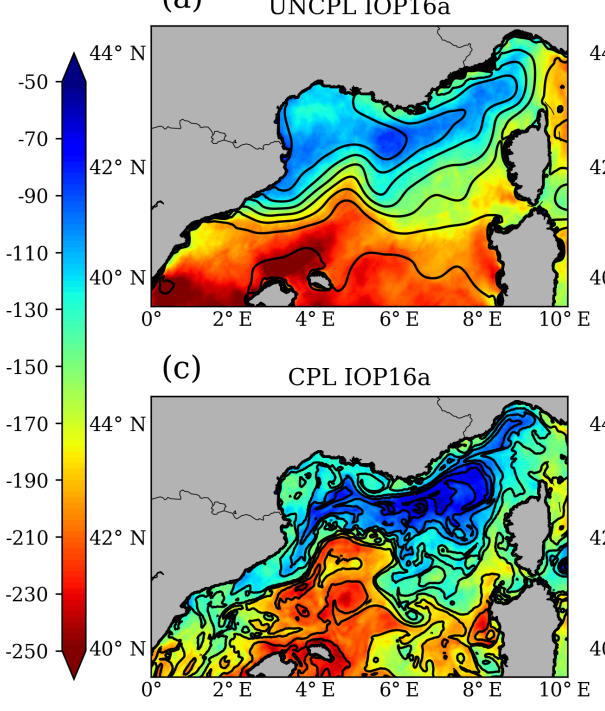

(e) CPL-UNCPL IOP16a

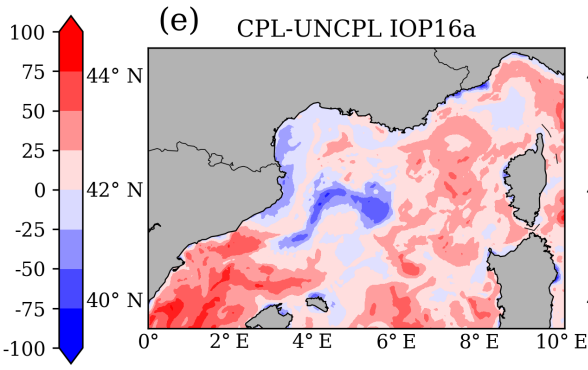

(b) UNCPL IOP16b

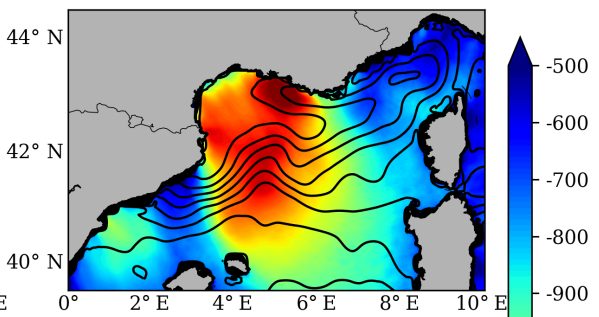

(d)

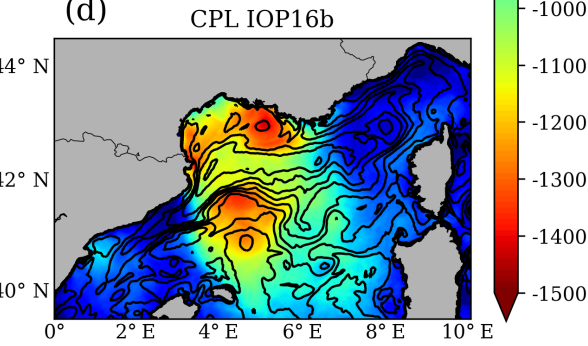

(f) CPL-UNCPL IOP16b

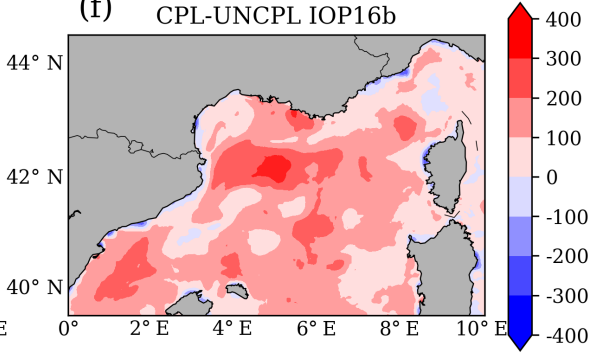

Figure 6. Spatial distribution of non-solar heat flux $\left(\mathrm{Qns}, \mathrm{W} \mathrm{m}^{-2}\right.$ ) and $\mathrm{SST}$ in black contours (contour interval of $\left.0.5^{\circ} \mathrm{C}\right)$ averaged over IOP16a (left) and IOP16b (right) for UNCPL simulation (a, b), CPL simulation (c, d) and the difference between CPL and UNCPL (e, f).

WW3) wave model (Tolman, 2002, 2009). The three models cover almost the same spatial area (Fig. 2f). The horizontal resolution of MESONH is $2 \mathrm{~km}$ and its initial conditions are provided by AROME operational analyses. MARS3D is run with a horizontal resolution of $500 \mathrm{~m}$ and its initial and boundary conditions come from coastal operational oceanography system Prévimer (Lazure et al., 2009) using the $2.5 \mathrm{~km}$ Bay of Biscay configuration. WW3 is used with a spatial resolution of about $1.5 \mathrm{~km}$ and its spectral resolution corresponds to 32 frequencies ranging from 0.0373 to $0.7159 \mathrm{~Hz}$ and 24 points for the propagation direction (every $15^{\circ}$ ). At open boundaries, WW3 is forced by 3-hourly energy spectra from the HOMERE hindcast database (Boudière et al., 2013). The atmospheric roughness length is estimated from the Charnock parameter supplied by WW3 (Eq. 9). The coupling frequency between the three models is $100 \mathrm{~s}$.

The $\mathrm{M} 2 \mathrm{~W}$ simulation is performed over a $24 \mathrm{~h}$ period starting on 2 September 2011 at 00:00 UTC. Figure 8 shows an example of the impact of the ocean dynamics and of the sea state on the wind stress. On 2 September 2011 at 09:00 UTC, winds are moderate. In the $\mathrm{M} 2 \mathrm{~W}$ simulation, the wind stress is largely driven by the mesoscale and sub-mesoscale dynamics of the Ushant Front, through the sea surface temper- ature (Fig. 8a) and the surface roughness (Fig. 8b). The wind stress weakens when air blows from warm to cold sea surface temperature regions (Fig. 8a). The roughness length is larger where the wind maintains a young wind sea and in the Channel (Fig. 8b). The wave impact is illustrated by comparing the fully coupled ocean-atmosphere-wave system (M2W) to the MESONH-MARS coupled system (M2, without WAV coupling). In this latter case, the roughness length depends on the wind only. Both the differences in the wind (Fig. 8c) and the roughness length (Fig. 8d) show a clear dependence on the wind sea representation where the wind is stronger, triggering a wind sea growth, and around the islands. Further investigations are ongoing to better parameterize the wave effect on the momentum flux, including the evaluation of the second approach implemented in SURFEX described in Sect. 2.4.2.

\section{Conclusions and perspectives}

The SURFEX platform considers various surface properties using sophisticated parameterizations and provides the surface fluxes of heat, water, momentum and carbon to the atmosphere. As it can be used in stand-alone mode but 

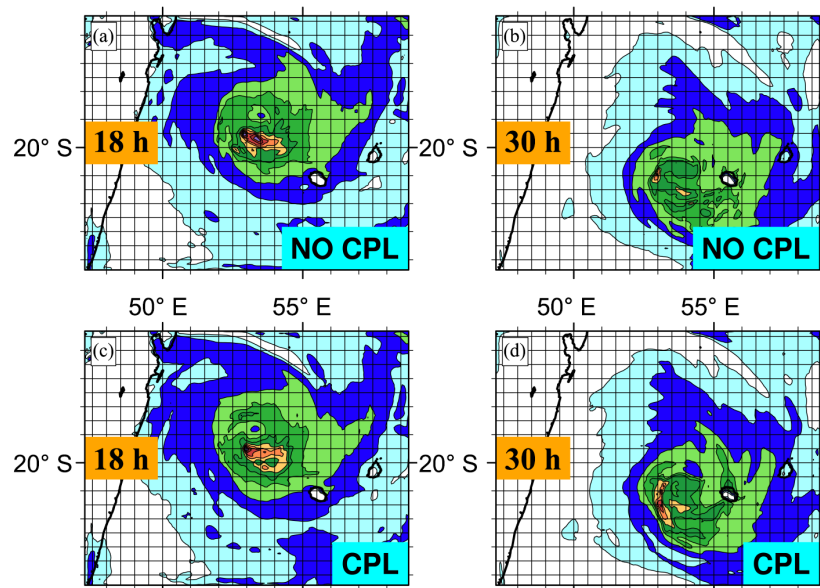

$50^{\circ} \mathrm{E}$

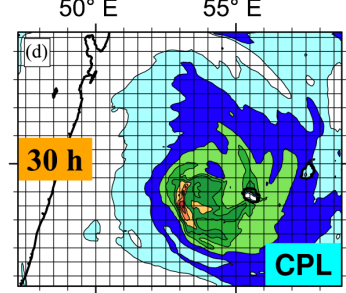

$50^{\circ} \mathrm{E}$ $55^{\circ} \mathrm{E}$

$50^{\circ}$ $50^{\circ}$ $55^{\circ} \mathrm{E}$

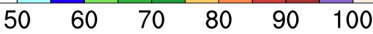

Figure 7. Total integrated water content in millimetres after $18 \mathrm{~h}$ (a, c) and $30 \mathrm{~h} \mathrm{(b,} \mathrm{d)} \mathrm{of} \mathrm{simulation,} \mathrm{respectively.} \mathrm{The} \mathrm{top} \mathrm{pan-}$ els $(\mathbf{a}, \mathbf{b})$ show results for the non-coupled system (NOCPL, i.e atmosphere-only) and the bottom panels (c, d) show results for the coupled system (CPL).

also integrated in many atmospheric models, this platform can be used for various kinds of applications - from academic simulations to numerical weather forecast and climate projections - and over a wide range of spatial scales and resolutions, from local sites to global climate model scales. A quite generic interface with OASIS3-MCT was implemented in SURFEX to allow the coupling of this surface model to physically elaborated hydrological, ocean/seaice and wave models. The standard coupling interface with OASIS3-MCT is now part of version 8.0 of SURFEX for ocean/sea-ice/hydrology coupling. The coupling with wave models will be available with version 8.1 .

One of the strengths of this approach is that all atmospheric models using SURFEX share the ability to be coupled with ocean/wave/hydrological models. As shown in Sect. 3, this standard interface has already been successfully used with several atmospheric and ocean models for diverse purposes. Indeed, the six coupled systems presented here show a wide panel of applications using SURFEX and OASIS3-MCT, in terms of spatial resolution (from $500 \mathrm{~m}$ to $100 \mathrm{~km}$ in the ocean and from 2.5 to $140 \mathrm{~km}$ in the atmosphere), and in terms of scientific objectives: climate projections (CNRM-CM6), regional climate studies (CNRM-RCSM6), weather forecasts (AROMENEMO WMED), ocean-atmosphere interaction and extreme events (MESONH-Symphonie and MESONH-NEMO Indian Ocean), and very fine-scale processes (MESONHMARS3D-WW3).

The inclusion of the coupling interface in SURFEX also presents several advantages. First, sharing a standard cou- pling interface favours the scientific collaboration between SURFEX users, and so any future development will be readily available to all SURFEX users. In addition, any new development in SURFEX is easily integrable and testable in a coupled system. This is of particular interest to test surface flux parameterizations which are critical physical schemes in coupled mode. But, most of all, the coupling interface with OASIS3-MCT associated with the rich surface physics included in SURFEX constitutes a very flexible and advanced numerical tool to build integrated systems, to evaluate the exchanges at each interface, and thus to fully study the water, heat and carbon cycles.

The chosen coupling strategy using the OASIS3-MCT coupler permits us to minimize modifications in the existing codes and imposes finally only the maintenance of the few coupling interface sources in SURFEX. Running multiple executables concurrently may not always be optimal, in particular for components sequentially coupled. The applications described here show that the computational cost of the OASIS3-MCT interface is negligible compared to the cost of the individual model components. Additionally, the computational cost of the atmospheric component represents more than $55 \%$ of the total coupled model cost in all applications presented here. This ratio is even greater than $80 \%$ for CNRM-CM, CNRM-RCSM, AROME-NEMO and MESONH-SYMPHONIE, meaning that the computational cost of atmospheric applications is not severely impacted by the coupling in these cases. This is a crucial point in the perspective of high-resolution coupled numerical weather prediction systems.

The SURFEX-OASIS interface provides a large flexibility for coupling in terms of number or kinds of involved models or in terms of scales, resolutions and domains. This greatly facilitates the development of new coupled systems, even if caution must always be taken. For example, even if there is no specific work to be done for the coupling in itself, changing the region for limited-area coupled systems necessitates adaptation of each component and careful definition of the corresponding grids and masks for OASIS3-MCT (as mentioned in Sect. 2.3). Also, the OASIS3-MCT namelist (namcouple) must always be carefully edited by the user, notably for the exchange field names and for the interpolation methods.

Finally, the ability of SURFEX to run in stand-alone mode (driven by atmospheric forcings) offers new opportunities for model evaluation. Ocean models are usually run either forced by fluxes or forced by near-surface atmospheric fields. In the last case, bulk formulae are embedded in the ocean code to calculate turbulent fluxes. The comparison with coupled runs is not straightforward in this case as bulk formulae used in the ocean code are not the same as those used in the coupled system. Using SURFEX on top of the ocean model in forced mode would resolve this issue as the fluxes would be calculated in SURFEX with the exact method used in coupled mode. A SURFEX-OCE-HYD configuration also allows us 

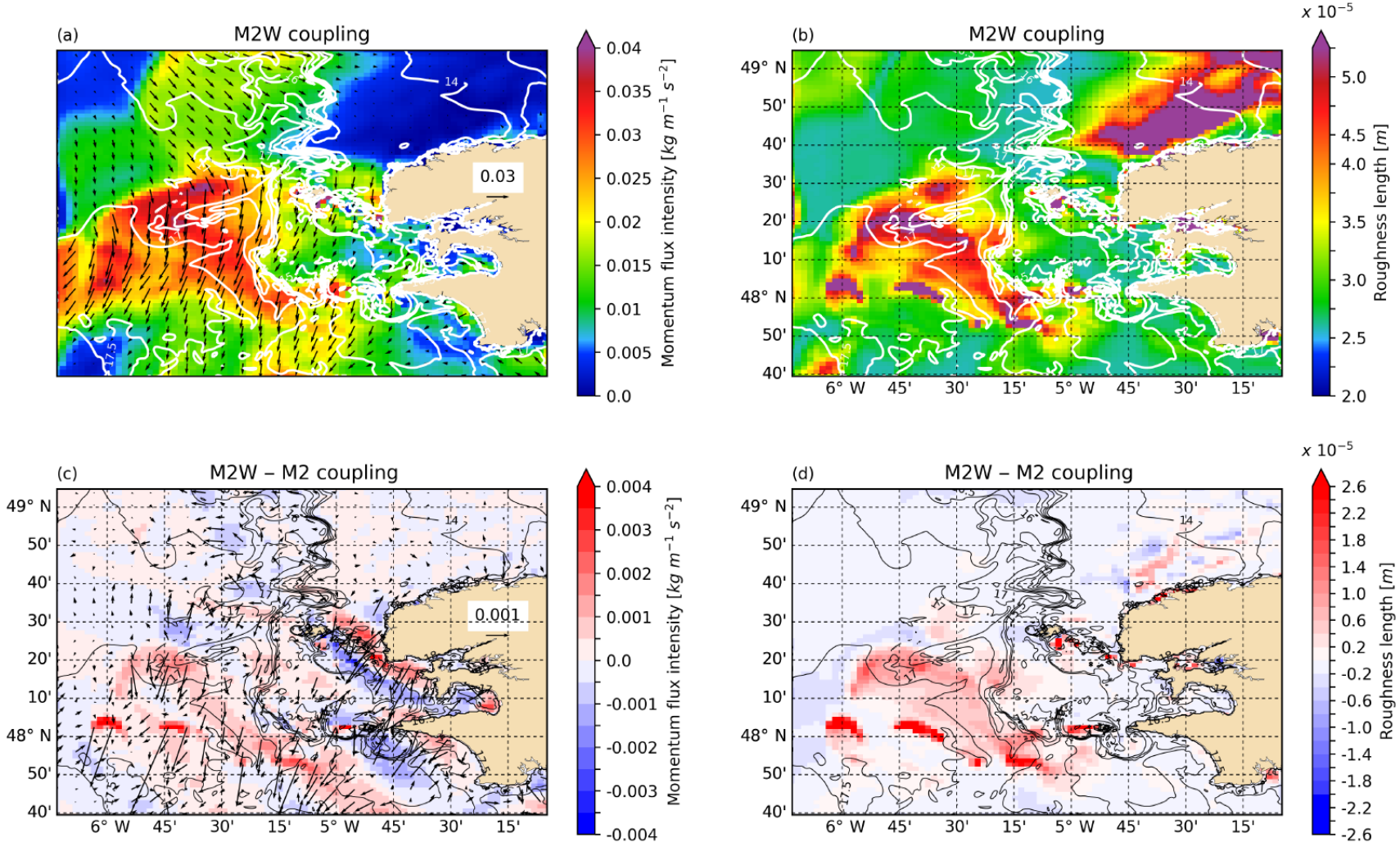

Figure 8. (a) Wind stress module (colour) and vector (arrows) (atmospheric sign convention), and SST (white contours with $0.5^{\circ} \mathrm{C}$ interval) simulated by M2W. (b) Roughness length (colour) and SST (white contours with $0.5^{\circ} \mathrm{C}$ interval) simulated by M2W. (c) Differences of the wind stress module (colour) and vector (arrows) when simulated by M2W versus M2. (d) Differences of the roughness length (colour) and the SST (black contours with $0.5^{\circ} \mathrm{C}$ interval) simulated by M2W versus M2. All fields are shown at 09:00 UTC, $2 \mathrm{~h}$ after high tide.

to run the whole surface hydrological water cycle forced by an atmospheric observed forcing.

It is often hard to clearly isolate the pure coupling effect in existing applications, and it is not the purpose of this paper. In most cases, comparison of coupled and uncoupled simulations rather shows the benefit of using a more detailed SST field in terms of space and time variations than the pure coupling effect. Nevertheless, for operational purposes, coupled models appear to be very promising tools able to represent and take into account the rapid SST evolution in coherence (balance) with the atmosphere. It actually compensates for the general lack of observations of the sea surface, even greater in severe weather situations, related to the too few in situ data over the ocean and to the larger number of missing satellite observations in cloudy situations.

Similarly for climate studies, long-term simulations have to be run including the ocean and sea-ice components. The main question is rather to assess whether model performances are not greatly altered by the coupling, keeping in mind that introducing the coupling is a step towards a more physical representation of the mixed layers in both the ocean and atmospheric systems.
Some improvements of the coupling interface are planned in the near future. First, new coupling fields should be introduced, such as ocean salinity, which has an impact on water fluxes, marine aerosol emission and carbon concentration to close the global carbon cycle. Adding a new coupling field is straightforward as the developer only needs to define the new variable and to add the action of receiving (or sending) the field. The way currents interact with the momentum budget also has to be improved. The physical representations of some key processes, such as the wave effect into the surface atmospheric boundary layer or the interactions between sea ice and waves, require further investigations.

The question of the two-way nesting in the component models was not addressed during the implementation, while this possibility is proposed by several models presented here (NEMO with AGRIF or MESONH) and opens great perspectives for the study of coupled processes. Several developments must be undertaken before using the coupling interface with grid nesting, notably to manage with OASIS3-MCT the use of several domains within one executable.

Finally, there is also a need to work on coupled model initialization techniques. Indeed, the initial (and lateral boundary) conditions generally arise from uncoupled systems that 
may lead to inconsistencies near the interface and could necessitate an adjustment period at the beginning of coupled simulation. Even if, in atmospheric and oceanic models, assimilation methods are at a rather mature stage, this is a new research field for coupled models (Laloyaux et al., 2016).

Code availability. The OASIS3-MCT-SURFEX interface is available in version 8 of SURFEX (http://www.cnrm-game-meteo.fr/ surfex). The SURFEX code is freely available (Open-SURFEX) using a CECILL-C Licence (a French equivalent of the L-GPL licence; http://www.cecill.info/licences/Licence_CeCILL-C_V1-en. txt), excepted for the gaussian grid, the LFI and FA I/O formats, and the dr HOOK tool. OASIS3-MCT can be downloaded at https://verc.enes.org/oasis/download. The public may copy, distribute, use, prepare derivative works and publicly display OASIS3MCT under the terms of the Lesser GNU General Public License (LGPL) as published by the Free Software Foundation, provided that this notice and any statement of authorship are reproduced on all copies. The NEMO model can be downloaded at http://www.nemo-ocean.eu/ after a user registration on the NEMO website, the NEMOMED12 configuration is available on request to thomas.arsouze@ensta-paristech.fr, and NEMO-WMED36 is available on request to cindy.lebeaupin-brossier@meteo.fr. The SYMPHONIE model can be downloaded at http://sirocco.omp.obs-mip. fr/ after a user registration on request to sirocco@aero.obs-mip.fr. The use of MARS3D model requires a license agreement (contact on the website). Once registered on the MARS3D website, users can access the USHANT configuration on request to valerie.garnier@ifremer.fr. MESONH is freely available under the CeCILL-C licence agreement. Version 5.3 includes SURFEX v8_0 and thus the coupling interface with OASIS3-MCT (for ocean/seaice/hydrology). MESONH can be downloaded at http://mesonh. aero.obs-mip.fr/mesonh53/. WW3 is distributed under an opensource style license through a password-protected distribution site at http://polar.ncep.noaa.gov/waves/wavewatch/. ARPEGE, ALADIN and AROME are not available in open source. ARPEGEClimate is available to registered users for research purposes only. Outputs from all models discussed here are available on request to the authors.

Author contributions. AA managed and tested the ARPEGEClimate/ALADIN-Climate models, and their SURFEX interface code. SB developed and validated the MESONH-NEMO coupled system in the SWIO. BD coded the SURFEX-OASIS interface and the CTRIP-OASIS3-MCT interface, and used them in climate hydrological and global model applications. VD is the coordinator/investigator of the SURFEX-OASIS interface development team. SF is in charge of the SURFEX code management. CLB adapted the SURFEX-OASIS interface to limited-area models and made its verification with the development of the AROME-NEMO WMED coupled system. FL, RR, HG and SR were involved in the AROME-NEMO WMED application and validation. JP, VG, MNB, JLR, MA and FA developed the ocean-atmosphere-wave coupling and its application in the Iroise Sea. LS, PM and ER developed and validated the MESONH-SYMPHONIE coupled system. FS developed and validated the ALADIN-NEMOMED12-CTRIP coupled system. SV is in charge of the OASIS3-MCT development.
AV made the SURFEX-OASIS interface technical development and tested it in the global climate model.

Competing interests. The authors declare that they have no conflict of interest.

Acknowledgements. The authors acknowledge the MISTRALS/HyMeX program and the ANR-2012-BS06-0003 ASICS-Med funding. The authors acknowledge the DGA (Direction Générale de l'Armement), a part of the French Ministry of Defense, for its contribution to Romain Rainaud's $\mathrm{PhD}$, as well as the coastal part of the Copernicus project co-funded by the MEDDE (French Ministry of Ecology, Sustainable Development and Energy) and INSU (National Institute of Sciences and Universe).

The authors acknowledge Edmée Durand and Yann Drillet from Mercator Océan technical support. Simulations of the MESONHSYMPHONIE coupled system were performed using HPC resources from CALMIP (grants P09115 and P1325). The M2W calculation was performed with the HPC facilities of "Pôle de Calcul Intensif pour la Mer, PCIM", http://www.ifremer.fr/pcim.

OASIS3-MCT development was supported by the ESiWACE H2020 European project, grant agreement no. 675191 (www.esiwace.eu), the IS-ENES2 FP7 European project, contract number 312979 (https://verc.enes.org/ISENES2), and the CONVERGENCE project funded by the French National Research Agency, ANR-13-MONU-0008.

Edited by: Astrid Kerkweg

Reviewed by: three anonymous referees

\section{References}

Balmaseda, M. A., Trenberth, K. E., and Källén, E.: Distinctive climate signals in reanalysis of global ocean heat content, Geophys. Res. Lett., 40, 1754-1759, https://doi.org/10.1002/grl.50382, 2013.

Belamari, S.: Report on uncertainty estimates of an optimal bulk formulation for turbulent fluxes, MERSEA IP Deliverable, D.4.1.2, 31 pp., 2005.

Belamari, S. and Pirani, A.: Validation of the optimal heat and momentum fluxes using the ORCA-LIM global ocean-ice model, MERSEA IP Deliverable, D.4.1.3, 88 pp., 2007.

Berrisford, P., Dee, D., Fielding, K., Fuentes, M. N., Kallberg, P., Kobayashi, S., and Uppala, S.: The ERA-Interim Archive, ERA report series, 1, 1-16, 2009.

Best, M. J., Beljaars, A., Polcher, J., and Viterbo, P.: A Proposed Structure for Coupling Tiled Surfaces with the Planetary Boundary Layer, J. Hydrometeorol., 5, 1271-1278, 2004.

Beuvier, J., Béranger, K., Lebeaupin-Brossier, C., Somot, S., Sevault, F., Drillet, Y., Bourdallé-Badie, R., Ferry, N., and Lyard, F. Spreading of the Western Mediterranean Deep Water after winter 2005: Time scales and deep cyclone transport, J. Geophys. Res., 117, C07019, https://doi.org/10.1029/2011JC007679, 2012.

Booij, N., Ris, R. C., and Holthuijsen, L. H.: A thirdgeneration wave model for coastal regions. 1. Model de- 
scription and validation, J. Geophys. Res., 104, 7649-7666, https://doi.org/10.1029/98JC02622, 1999.

Boone, A., Masson, V., Meyers, T., and Noilhan, J.: The influence of the inclusion of soil freezing on simulation by a soil-atmospheretransfer scheme, J. Appl. Meteorol., 9, 1544-1569, 2000.

Boudière, E., Maisondieu, C., Ardhuin, F., Accensi, M., Pineau-Guillou, L., and Lepesqueur, J.: A suitable metocean hindcast database for the design of Marine energy converters, Int. J. Marine Energy, 3-4, e40-e52, https://doi.org/10.1016/j.ijome.2013.11.010, 2013.

Bouilloud, L., Chancibault, K., Vincendon, B., Ducrocq, V., Habets, F., Saulnier, G.-M., Anquetin, S., Martin, E., and Noilhan, J.: Coupling the ISBA land surface model and the TOPMODEL hydrological model for Mediterranean flash-flood forecasting: Description, calibration and validation, J. Hydrometeorol., 11, 315333, 2009.

Brassington, G. B., Martin, M. J., Tolman, H. L., Akella, S., Balmaseda, M., Chambers, C. R. S., Chassignet, E., Cummings, J. A., Drillet, Y., Jansen, P. A. E. M., Laloyaux, P., Lea, D., Mehra, A., Mirouze, I., Ritchie, H., Samson, G., Sandery, P. A., Smith, G. C., Suarez, M., and Todling, R.: Progress and challenges in short- to mediumrange coupled prediction, J. Operation. Oceanogr., 8, s359-s258, https://doi.org/10.1080/1755876X.2015.1049875, 2015.

Breivik, Ø., Janssen, P. A. E. M., and Bidlot, J.-R.: Approximate Stokes Drift Profiles in Deep Water, J. Phys. Oceanogr, 44, 2433 2445, https://doi.org/10.1175/JPO-D-14-0020.1, 2014.

Carniel, S., Benetazzo, A., Bonaldo, D., Falcieri, F. M., Miglietta, M. M., Ricchi, A., and Sclavo, M.: Scratching beneath the surface while coupling atmosphere, ocean and waves: Analysis of a dense water formation event, Ocean Model., 101, 101-112, https://doi.org/10.1016/j.ocemod.2016.03.007, 2016.

Charnock, H.: Wind stress over a water surface, Q. J. Roy. Meteor. Soc., 81, 639-640, 1955.

Collins, N., Theurich, G., DeLuca, C., Suarez, M., Trayanov, A., Balaji, V., Li, P., Yang, W., Hill, C., and da Silva, A.: Design and implementation of components in the Earth System Modeling Framework, Int. J. High Perform. Comput. Appl., 19, 341350, https://doi.org/10.1177/1094342005056120, 2005.

Courtier, P., Freydier, C., Geleyn, J.-F., Rabier, F., and Rochas, M.: The ARPEGE project at Météo-France, ECMWF workshop on numerical methods in atmospheric modeling, 2, 193-231, 1991.

Craig, A., Valcke, S., and Coquart, L.: Development and performance of a new version of the OASIS coupler, OASIS3-MCT_3.0, Geosci. Model Dev., 10, 3297-3308, https://doi.org/10.5194/gmd-10-3297-2017, 2017.

Decharme, B. and Douville, H.: Introduction of a sub-grid hydrology in the ISBA land surface model, Clim. Dynam., 26, 65-78, 2006.

Decharme, B., Alkama, R., Douville, H., Becker, M., and Cazenave, A.: Global Evaluation of the ISBA-TRIP Continental Hydrological System. Part II : Uncertainties in River Routing Simulation Related to Flow Velocity and Groundwater Storage, J. Hydrometeorol., 11, 601-661, https://doi.org/10.1175/2010JHM1212.1, 2010.

Decharme, B., Boone, A., Delire, C., and Noilhan, J.: Local evaluation of the Interaction between Soil Biosphere Atmosphere soil multilayer diffusion scheme using four pedotransfer functions, J. Geophys. Res., 116, D20126, https://doi.org/10.1029/2011JD016002, 2011.

Decharme, B., Alkama, R., Papa, F., Faroux, S., Douville, H., and Prigent, C.: Global offline evaluation of the ISBA-TRIP flood model, Clim. Dynam., 38, 1389-1412, https://doi.org/10.1007/s00382-011-1054-9, 2012.

Decharme, B., Martin, E., and Faroux, S.: Reconciling soil thermal and hydrological lower boundary conditions in land surface models., J. Geophys. Res.-Atmos., 118, 7819-7834, https://doi.org/10.1002/jgrd.50631, 2013.

Decharme, B., Brun, E., Boone, A., Delire, C., Le Moigne, P., and Morin, S.: Impacts of snow and organic soils parameterization on northern Eurasian soil temperature profiles simulated by the ISBA land surface model, The Cryosphere, 10, 853-877, https://doi.org/10.5194/tc-10-853-2016, 2016.

Déqué, M., Dreveton, C., Braun, A., and Cariolle, D.: The ARPEGE-IFS atmosphere model: a contribution to the French community climate modelling, Clim. Dynam., 10, 249-266, 1994.

Donlon, C. J., Matthew, M., John, S., Jonah, R.-J., Emma, F., and Werenfrid, W.: The Operational Sea Surface Temperature and Sea Ice Analysis (OSTIA) system, Remote Sens. Environ., 116, 140-158, 2012.

Doyle, J. D., Hodur, R. M., Chen, S., Jin, Y., Moskaitis, J. R., Wang, S., Hendricks, E. A., Jin, H., and Smith, T. A.: Tropical cyclone prediction using COAMPS-TC, Oceanography, 27, 104-115, https://doi.org/10.5670/oceanog.2014.72, 2014.

Ducrocq, V., Braud, I., Davolio, S., Ferretti, R., Flamant, C., Jansa, A., Kalthoff, N., Richard, E., Taupier-Letage, I., Ayral, P. A., Belamari, S., Berne, A., Borga, M., Boudevillain, B., Bock, O., Boichard, J.-L., Bouin, M.-N., Bousquet, O., Bouvier, C., Chiggiato, J., Cimini, D., Corsmeier, U., Coppola, L., Cocquerez, P., Defer, E., Delano, J., Di Girolamo, P., Doerenbecher, A., Drobinski, P., Dufournet, Y., Fourrié, N., Gourley, J. J., Labatut, L., Lambert, D., Le Coz, J., Marzano, F. S., Molinié, G., Montani, A., Nord, G., Nuret, M., Ramage, K., Rison, B., Roussot, O., Said, F., Schwarzenboeck, A., Testor, P., Van Baelen, J., Vincendon, B., Aran, M., and Tamayo, J.: HYMEXSOP1, the field campaign dedicated to heavy precipitation and flash flooding in the northwestern Mediterranean, B. Am. Meteorol. Soc., 95, 1083-1100, https://doi.org/10.1175/BAMS-D-1200244.1, 2014.

Fairall, C., Bradley, E., Hare, J., Grachev, A., and Edson, J.: Bulk parameterization of air-sea fluxes updates and verification for the COARE algorithm, J. Climate, 16, 571-591, 2003.

Fischer, C., Montmerle, T., Berre, L., Auger, L., and Stefanescu, S. E.: An overview of the variational assimilation in the ALADIN/France numerical weather-prediction system, Q. J. Roy. Meteor. Soc., 131, 3477-3492, 2005.

Fourrié, N., Bresson, É., Nuret, M., Jany, C., Brousseau, P., Doerenbecher, A., Kreitz, M., Nuissier, O., Sevault, E., Bénichou, H., Amodei, M., and Pouponneau, F.: AROME-WMED, a real-time mesoscale model designed for the HyMeX special observation periods, Geosci. Model Dev., 8, 1919-1941, https://doi.org/10.5194/gmd-8-1919-2015, 2015.

Habets, F., Boone, A., Champeaux, J. L., Etchevers, P., Franchisteguy, L., Leblois, E., Ledoux, E., Le Moigne, P., Martin, E., Morel, S., Noilhan, J., Quintana Segui, P., Rousset-Regimbeau, F., and Viennot, P.: The SAFRAN-ISBA-MODCOU hydromete- 
orological model applied over France, J. Geophys. Res.-Atmos., 113, D06113, https://doi.org/10.1029/2007JD008548, 2008.

Habets, F., Boone, A., and Noilhan, J.: Simulation of a Scandinavian basin using the diffusion transfer version of ISBA, Global Planet. Change, 38, 137-149., 2003

Hamon, M., Beuvier, J., Somot, S., Lellouche, J.-M., Greiner, E., Jordà, G., Bouin, M.-N., Arsouze, T., Béranger, K., Sevault, F., Dubois, C., Drevillon, M., and Drillet, Y.: Design and validation of MEDRYS, a Mediterranean Sea reanalysis over the period 1992-2013, Ocean Sci., 12, 577-599, https://doi.org/10.5194/os12-577-2016, 2016.

Heinzeller, D., Duda, M. G., and Kunstmann, H.: Towards convection-resolving, global atmospheric simulations with the Model for Prediction Across Scales (MPAS) v3.1: an extreme scaling experiment, Geosci. Model Dev., 9, 77-110, https://doi.org/10.5194/gmd-9-77-2016, 2016.

Hewitt, H. T., Roberts, M. J., Hyder, P., Graham, T., Rae, J., Belcher, S. E., Bourdallé-Badie, R., Copsey, D., Coward, A., Guiavarch, C., Harris, C., Hill, R., Hirschi, J. J.-M., Madec, G., Mizielinski, M. S., Neininger, E., New, A. L., Rioual, J.-C., Sinha, B., Storkey, D., Shelly, A., Thorpe, L., and Wood, R. A.: The impact of resolving the Rossby radius at mid-latitudes in the ocean: results from a high-resolution version of the Met Office GC2 coupled model, Geosci. Model Dev., 9, 3655-3670, https://doi.org/10.5194/gmd-9-3655-2016, 2016.

Janssen, P. A. E. M., Doyle, J. D., Bidlot, J., Hansen, B., Isaksen, L., and Viterbo, P.: Impact and feedback of ocean waves on the atmosphere, ECMWF Technical Memoranda Series, no. 341, 32 pp., 2001.

Janssen, P., Breivik, Ø., Mogensen, K., Vitart, F., Alonso Balmaseda, M., Bidlot, J.-R., Keeley, S., Leutbecher, M., Magnusson, L., and Molteni, F.: Air-sea interaction and surface waves, ECMWF Technical Memoranda Series, no. 712, 34 pp., 2013.

Jones, P.: Conservative remapping: First- and second-order conservative remapping, Mon. Weather Rev., 127, 2204-2210, 1999.

Jung, M., Reichstein, M., and Bondeau, A.: Towards global empirical upscaling of FLUXNET eddy covariance observations: validation of a model tree ensemble approach using a biosphere model, Biogeosciences, 6, 2001-2013, https://doi.org/10.5194/bg-6-2001-2009, 2009.

Lafore, J-P., Stein, J., Asencio, N., Bougeault, P., Ducrocq, V., Duron, J., Fischer, C., Héreil, P., Mascart, P., Masson, V., Pinty, J.-P., Redelsperger, J.-L., Richard, E., and Vilà-Guerau de Arellano, J.: The Meso-NH Atmospheric Simulation System. Part I: adiabatic formulation and control simulations, Ann. Geophys., 16, 90-109, https://doi.org/10.1007/s00585-997-0090-6, 1998.

Laloyaux, M., Balmaseda, M., Dee, D., Morgensen, K., and Janssen, P.: A coupled data assimilation system for climate reanalysis, Q. J. Roy. Meteor. Soc., 142, 65-78, 2016.

Larson, J., Jacob, R., and Ong, E.: The Model Coupling Toolkit: A new fortran90 toolkit for building multiphysics parallel coupled models, Int. J. High Perf. Comp. App., 19, 277-292, 2005.

Lazure, P. and Dumas, F.: An external-internal mode coupling for a 3D hydrodynamical model for applications at regional scale (MARS), Adv. Water Resour., 31, 233-250, https://doi.org/10.1016/j.advwatres.2007.06.010, 2008.

Lazure, P., Garnier, V., Dumas, F., Herry, C., and Chifflet, M.: Development of a hydrodynamic model of the Bay of Bis- cay, Validation of hydrology, Cont. Shelf Res., 29, 985-997, https://doi.org/10.1016/j.csr.2008.12.017, 2009.

Lebeaupin Brossier, C., Arsouze, T., Béranger, K., Bouin, M.N., Bresson, E., Ducrocq, V., Giordani, H., Nuret, M., Rainaud, R., and Taupier-Letage, I.: Ocean mixed layer responses to intense meteorological events during HyMeX-SOP1 from a high-resolution ocean simulation, Ocean Model., 84, 84-103, https://doi.org/10.1016/j.ocemod.2014.09.009, 2014.

Lellouche, J.-M., Le Galloudec, O., Drévillon, M., Régnier, C., Greiner, E., Garric, G., Ferry, N., Desportes, C., Testut, C.-E., Bricaud, C., Bourdallé-Badie, R., Tranchant, B., Benkiran, M., Drillet, Y., Daudin, A., and De Nicola, C.: Evaluation of global monitoring and forecasting systems at Mercator Océan, Ocean Sci., 9, 57-81, https://doi.org/10.5194/os-9-57-2013, 2013.

Loglisci, N., Qian, M. W., Rachev, N., Cassardo, C., Longhetto, A., Purini, R., Trivero, P., Ferrarese, S., and Giraud, C.: Development of an atmosphere-ocean coupled model and its application over the Adriatic Sea during a severe weather event of Bora wind, J. Geophys. Res., 109, D01102, https://doi.org/10.1029/2003JD003956, 2004.

Louis, J.-F.: A parametric model of vertical eddy fluxes in the atmosphere, Bound.-Lay. Meteorol., 17, 187-202, 1979.

Madec, G. and the NEMO team: NEMO ocean engine, Note du Pole de modélisation, Institut Pierre-Simon Laplace (IPSL), France, 27, 1288-1619, 2008

Marsaleix, P., Auclair, F., Floor, J. W., Herrmann, M. J., Estournel, C., Pairaud, I., and Ulses, C.: Energy conservation issues in sigma-coordinate free-surface ocean models, Ocean Model., 20, 61-89, https://doi.org/10.1016/j.ocemod.2007.07.005, 2008.

Marsaleix, P., Auclair, F., and Estournel, C.: Low-order pressure gradient schemes in sigma coordinate models: The seamount test revisited, Ocean Model., 30, 169-177, https://doi.org/10.1016/j.ocemod.2009.06.011, 2009.

Marsaleix, P., Auclair, F., Estournel, C., Nguyen, C., and Ulses, C.: Alternatives to the Robert-Asselin filter, Ocean Model., 41, 5366, https://doi.org/10.1016/j.ocemod.2011.11.002, 2012.

Marshall, J. and Schott, F.: Open-ocean convection: Observations, theory and models, Rev. Geophys., 37, 1-64, 1999.

Masson, V.: A physically-based scheme for the urban energy budget in atmospheric models, Bound.-Lay. Meteorol., 94, 357-397, 2000.

Masson, V., Le Moigne, P., Martin, E., Faroux, S., Alias, A., Alkama, R., Belamari, S., Barbu, A., Boone, A., Bouyssel, F., Brousseau, P., Brun, E., Calvet, J.-C., Carrer, D., Decharme, B., Delire, C., Donier, S., Essaouini, K., Gibelin, A.-L., Giordani, H., Habets, F., Jidane, M., Kerdraon, G., Kourzeneva, E., Lafaysse, M., Lafont, S., Lebeaupin Brossier, C., Lemonsu, A., Mahfouf, J.-F., Marguinaud, P., Mokhtari, M., Morin, S., Pigeon, G., Salgado, R., Seity, Y., Taillefer, F., Tanguy, G., Tulet, P., Vincendon, B., Vionnet, V., and Voldoire, A.: The SURFEXv7.2 land and ocean surface platform for coupled or offline simulation of earth surface variables and fluxes, Geosci. Model Dev., 6, 929-960, https://doi.org/10.5194/gmd-6-929-2013, 2013.

Mironov, D., Heise, E., Kourzeneva, E., Ritter, B., Schneider, N. and Terzhevik, A.: Implementation of the lake parameterization scheme FLake into the numerical weather prediction model COSMO, Boreal Environ. Res., 15, 218-230, 2010. 
Noilhan, J. and Planton, S.: A Simple Parameterization of Land Surface Processes for Meteorological Models, Mon. Weather Rev., 117, 536-549, 1989.

Oost, W. A., Komen, G. J., Jacobs, C. M. J., and Van Oort, C.: New evidence for a relation between wind stress and wave age from measurements during ASGAMAGE, Bound.-Lay. Meteorol., 103, 409-438, https://doi.org/10.1023/A:1014913624535, 2002.

Pullen, J., Doyle, J. D., Hodur, R., Ogston, A., Book, J. W., Perkins, H., and Signell, R.: Coupled ocean-atmosphere nested modeling of the Adriatic Sea during winter and spring 2001, J. Geophys. Res., 108, 3320, https://doi.org/10.1029/2003JC001780, 2003.

Pullen, J., Doyle, J. D., and Signell, R.: Two-Way Air-Sea coupling: A study of the Adriatic, Mon. Weather Rev., 134, 1465-1483, 2006.

Pullen, J., Doyle, J. D., Haack, T., Dorman, C., Signell, R. P., and Lee, C. M.: Bora event variability and the role of air-sea feedback, J. Geophys. Res., 112, C03S18, https://doi.org/10.1029/2006JC003726, 2007.

Radu, R., Déqué, M., and Somot, S.: Spectral nudging in a spectral regional climate model, Tellus A, 60, 898-910., 2008

Rainaud, R., Lebeaupin Brossier, C., Ducrocq, V., and Giordani, H.: High-resolution air-sea coupling impact on two heavy precipitation events in the Western Mediterranean, Q. J. Roy. Meteor. Soc., 143, 2448-2462, https://doi.org/10.1002/qj.3098, 2017.

Ren, X., Perrie, W., Long, Z., and Gyakum, J.: AtmosphereOcean coupled dynamics of Cyclones in the Midlatitudes, Mon. Weather Rev., 132, 2432-2451, 2004.

Renault, L., Chiggiato, J., Warner, J. C., Gomez, M., Vizoso, G., and Tintoré, J.: Coupled atmosphere oceanwave simulations of a storm event over the Gulf of Lion and Balearic Sea, J. Geophys. Res., 117, C09019, https://doi.org/10.1029/2012JC007924, 2012.

Ricchi, A., Miglietta, M. M., Falco, P. P., Benetazzo, A., Bonaldo, D., Bergamasco, A., Sclavo, M., and Carniel, S.: On the use of a coupled ocean-atmosphere-wave model during an extreme cold air outbreak over the Adriatic Sea, Atmos. Res., 172-173, 48-65, https://doi.org/10.1016/j.atmosres.2015.12.023, 2016.

Ruti, P., Somot, S., Giorgi, F., Dubois, C., Flaounas, E., Obermann, A., Dell'Aquila, A., Pisacane, G., Harzallah, A., Lombardi, E., Ahrens, B., Akhtar, N., Alias, A., Arsouze, T., Aznar, R., Bastin, S., Bartholy, J., Béranger, K., Beuvier, J., Bouffies-Cloché, S., Brauch, J., Cabos, W., Calmanti, S., Calvet, J.-C., Carillo, A., Conte, D., Coppola, E., Djurdjevic, V., Drobinski, P., ElizaldeArellano, A., Gaertner, M., Galàn, P., Gallardo, C., Gualdi, S., Goncalves, M., Jorba, O., Jordà, G., L'Heveder, B., Lebeaupin Brossier, C., Li, L., Liguori, G., Lionello, P., Maciàs, D., Nabat, P., Onol, B., Raikovic, B., Ramage, K., Sevault, F., Sannino, G., Struglia, M. V., Sanna, A., Torma, C., and Vervatis, V.: MedCORDEX initiative for Mediterranean climate studies. B. Am. Meteorol. Soc., 97, 1187-1208, https://doi.org/10.1175/BAMSD-14-00176.1, 2016.

Salisbury, D. J., Anguelova, M. D., and Brooks, I. M.: On the variability of whitecap fraction using satellite-based observations, J. Geophys. Res.-Oceans, 118, 6201-6222, https://doi.org/10.1002/2013JC008797, 2013.

Séférian, R., Baek, S., Boucher, O., Dufresne, J.-L., Decharme, B., Saint-Martin, D., and Roehrig, R.: An interactive ocean surface albedo scheme: formulation and evaluation in two atmospheric models, Geosci. Model Dev. Discuss., https://doi.org/10.5194/gmd-2017-111, in review, 2017.

Seity, Y., Brousseau, P., Malardel, S., Hello, G., Bénard, P., Bouttier, F., Lac, C., and Masson, V.: The AROME-France convective scale operational model, Mon. Weather Rev., 139, 976-991, 2011.

Seyfried, L., Marsaleix, P., Richard, E., and Estournel, C.: Modelling deep-water formation in the North-West Mediterranean Sea with a new air-sea coupled model: sensitivity to turbulent flux parameterizations, Ocean Sci. Discuss., https://doi.org/10.5194/os-2017-43, in review, 2017.

Shchepetkin, A. F. and McWilliams, J. C.: The regional oceanic modeling system (ROMS): A split explicit, free-surface, topography-following-coordinate oceanic model, Ocean Model., 9, 347-404, https://doi.org/10.1016/j.ocemod.2004.08.002, 2005.

Sheffield, J., Goteti, G., and Wood, E. F.: Development of a 50year high-resolution global data set of meteorological forcings for land surface modeling, J. Climate, 19, 3088-3111, 2006.

Skamarock, W. C., Klemp, J. B., Dudhia, J., Gill, D. O., Barker, D. M., Duda, M., Huang, X. Y., Wang, W., and Powers, J. G.: A Description of the Advanced Research WRF Version 3, NCAR Tech. Note NCAR/TN-475+STR, Natl. Cent. for Atmos. Res., Boulder, Colo, 2008.

Small, R. J., Campbell, T., Texeira, J., Carniel, S., Smith, T. A., Dykes, J., Chen, S., and Allard, R.: Air-Sea Interaction in the Ligurian Sea: Assessment of a Coupled Ocean-Atmosphere Model Using In Situ Data from LASIE07, Mon. Weather Rev., 139, 1785-1808, 2011.

Small, R. J., Carniel, S., Campbell, T., Texeira, J., and Allard, R.: The response of the Ligurian and Tyrrhenian Seas to a summer Mistral event: A coupled atmosphere-ocean approach, Ocean Model., 48, 30-44, 2012.

Smith, S. D.: Coefficients for sea surface wind stress, heat flux, and wind profiles as a function of wind speed and temperature, J. Geophys. Res., 93, 15467-15472, 1988.

Spiridonov, V., Somot, S., and Déqué, M.: ALADIN-Climate : from the origins to present date, ALADIN Newsletter, 29, 89-92, 2005.

Taylor, J. P., Edwards, J. M., Glew, M. D., Hignett, P., and Slingo, A.: Studies with a flexible new radiation code. II: Comparisons with aircraft short-wave observations, Q. J. Roy. Meteorol. Soc., 122, 839-861, 1996.

Taylor, P. K. and Yelland, M. J.: The dependence of sea surface roughness on the height and steepness of the waves, J. Phys. Ocean., 31, 572-590, 2001.

Theurich, G., DeLuca, C., Campbell, T., Liu, F., Saint, K., Vertenstein, M., Chen, J., Oehmke, R., Doyle, J., Whitcomb, T., Wallcraft, A., Iredell, M., Black, T., Da Silva, A., Clune, T., Ferraro, R., Li, P., Kelley, M., Aleinov, I., Balaji, V., Zadeh, N., Jacob, R., Kirtman, B., Giraldo, F., McCarren, D., Sandgathe, S., Peckham, S., and Dunlap, R.: The Earth System Prediction Suite: Toward a Coordinated U.S. Modeling Capability, B. Am. Meteor. Soc., 97, 1229-1247, https://doi.org/10.1175/BAMS-D-1400164.1, 2016.

Tolman, H. L.: Validation of WAVEWATCH-III version 1.15. Tech. Rep. no 213, 33 pp., NOAA/NWS/NCEP/MMAB, 2002

Tolman, H. L.: User Manual and System Documentation of WAVEWATCH III TM Version 3.14. NCEP Tech. Note, 220 pp., 2009. 
Valcke, S.: The OASIS3 coupler: a European climate modelling community software, Geosci. Model Dev., 6, 373-388, https://doi.org/10.5194/gmd-6-373-2013, 2013.

Valcke, S., Craig, T., and Coquart, L.: OASIS3-MCT User Guide, OASIS3-MCT_3.0. Tech. Rep. TR/CMGC/15/38, Cerfacs, France, 2015.

Vergnes, J.-P., Decharme, B., and Habets, F.: Introduction of groundwater capillary rises using subgrid spatial variability of topography into the ISBA land surface model, J. Geophys. Res.-Atmos., 119, 11065-11086, https://doi.org/10.1002/2014JD021573, 2014.

Voldoire, A., Sanchez-Gomez, E., Salas y Mélia, D., Decharme, B., Cassou, C., Sénési, S., Valcke, S., Beau, I., Alias, A., Chevallier, M., Déqué, M., Deshayes, J., Douville, H., Fernandez, E., Madec, G., Maisonnave, E., Moine, M.-P., Planton, S., Saint-Martin, D., Szopa, S., Tyteca, S., Alkama, R., Belamari, S., Braun, A., Coquart, L., and Chauvin, F.: The CNRMCM5.1 global climate model: description and basic evaluation, Clim. Dynam., 40, 2091-2121, https://doi.org/10.1007/s00382011-1259-y, 2013.
Warner, J. C., Sherwood, C. R., Signell, R. P., Harris, C., and Arango, H. G.: Development of a three-dimensional, regional, coupled wave, current, and sediment-transport model, Comput. Geosci., 34, 1284-1306, 2008.

Warner, J. C., Armstrong, B., He, R., and Zambon, J. B.: Development of a Coupled Ocean-Atmosphere-Wave-Sediment Transport (COAWST) modeling system, Ocean Model., 35, 230-244, https://doi.org/10.1016/j.ocemod.2010.07.010, 2010. 